\title{
Late Pleistocene interactions of East and West Antarctic ice-flow regimes: evidence from the McMurdo Ice Shelf
}

\author{
Thomas B. Kellogg, Terry Hughes and Davida E. Kellogg \\ Department of Geological Sciences and Institute for Quaternary Studies, University of Maine, Orono, Maine 04469, U.S.A.
}

\begin{abstract}
We present new interpretations of deglaciation in McMurdo Sound and the western Ross Sea, with observationally based reconstructions of interactions between East and West Antarctic ice at the last glacial maximum (LGM), 16000, 12000,8000 and $4000 \mathrm{BP}$. At the LGM, East Antarctic ice from Mulock Glacier split; one branch turned westward south of Ross Island but the other branch rounded Ross Island before flowing southwest into McMurdo Sound. This flow regime, constrained by an ice saddle north of Ross Island, is consistent with the reconstruction of Stuiver and others (1981a). After the LGM, grounding-line retreat was most rapid in areas with greatest water depth, especially along the Victoria Land coast. By $12000 \mathrm{BP}$, the ice-flow regime in McMurdo Sound changed to through-flowing Mulock Glacier ice, with lesser contributions from Koettlitz, Blue and Ferrar Glaciers, because the former ice saddle north of Ross Island was replaced by a dome. The modern flow regime was established $\sim 4000$ BP. Ice derived from high elevations on the Polar Plateau but now stranded on the McMurdo Ice Shelf, and the pattern of the Transantarctic Mountains erratics support our reconstructions of Mulock Glacier ice rounding Minna Bluff but with all ice from Skelton Glacier ablating south of the bluff. They are inconsistent with Drewry's (1979) LGM reconstruction that includes Skelton Glacier ice in the McMurdo Sound through-flow. Drewry's (1979) model closely approximates our results for $12000-4000 \mathrm{BP}$. Ice-sheet modeling holds promise for determining whether deglaciation proceeded by grounding-line retreat of an ice sheet that was largely stagnant, because it never approached equilibrium flowline profiles after the Ross Ice Shelf grounded, or of a dynamic ice sheet with flowline profiles kept low by active ice streams that extended northward from present-day outlet glaciers after the Ross Ice Shelf grounded.
\end{abstract}

\section{INTRODUCTION}

One key objective of the West Antarctic ice sheet (WAIS) initiative is documentation of eustatic sea-level change resulting from the possible disintegration of the West Antarctic ice sheet (Bindschadler, 1991). This effort requires detailed knowledge of ice-sheet history in West Antarctica, including the history of grounding-line and calving-margin retreat to the positions now occupied by these features and an accurate dynamic overview of the West Antarctic ice sheet, including present and former precipitation sources, flow regimes and changing interactions with ice derived from East Antarctica. The development of reliable predictive models for future ice-sheet retreat depends on these data. Yet, so far most WAIS studies have concentrated either on modern ice dynamics in West Antarctica or on elucidating former ice maxima.

This paper presents a series of preliminary observationally based reconstructions of interactions between the East and West Antarctic ice sheets during and since the last glacial maximum (LGM). These two ice sheets are separated by a dividing wall (the Transantarctic Mountains) and interact today primarily where throughflowing outlet glaciers from East Antarctica impinge on the Ross Ice Shelf. Our reconstructions are based on glacial geologic observations and the observed presentday ice dynamics of the McMurdo Ice Shelf (MIS), a part of the Ross Ice Shelf. The reconstructions aid in elucidating modern glaciological processes operating on this ice shelf and support suggestions by Kellogg and others (1990) that some existing MIS features are remnants from a former ice-flow regime. MIS data permit evaluation of two different published reconstructions of the flow regime during the LGM, and development of four new reconstructions for the Ross Sea embayment during the deglacial transition from the grounded late Wisconsin Ross Sea ice sheet to the modern Ross Ice Shelf, all of which include ice derived from both East Antarctica and West Antarctica.

West Antarctica is a key area for studying glacial history and dynamics, because the world's largest extant marine-based ice sheet is located there. Of particular importance are the Dry Valleys of southern Victoria Land, situated between the seasonally open waters of the Ross Sea and McMurdo Sound on the east and the East Antarctic ice sheet to the west. These ice-free valleys are shielded from direct East Antarctic ice-sheet influence by the Transantarctic Mountains. It can be argued that a third major factor, in addition to East and West Antarctic ice fluctuations, operates in this area: local glaciers 
respond to the proximity of an open-water moisture source in the Ross Sea. This influence is actually controlled by West Antarctic ice extent, being insignificant during glacial maxima and reaching its greatest importance during interglacials when shelf- and sea-ice limits are least extensive. The availability of a local moisture source is important for this paper primarily with respect to fluctuations of Koettlitz and Skelton Glaciers. A detailed late Quaternary paleoclimatic record for the Dry Valleys region (Denton and others, 1971, 1989; Stuiver and others, 1981a) shows that the dominant features were periodic advances of the West Antarctic ice sheet, which thickened and grounded in the Ross Sea and McMurdo Sound, pushing lobes of grounded ice into the Dry Valleys and leaving a record of ice-dammed lakes, marginal and recessional moraines and raised beaches. Numerous conventional ${ }^{14} \mathrm{C}$ dates on marine shells and terrestrial fresh-water algae suggest a late Quaternary age of $\sim 18-20 \mathrm{BP}$ for the most recent advance of West Antarctic ice (Ross Sea ice sheet). Drewry (1979) suggested that grounded ice extent was considerably less extensive than portrayed by Stuiver and others (1981a) and hence that their ice-flow trajectories were unlikely. In particular, Drewry (1979) called for northward flow of grounded ice past Ross Island in McMurdo Sound, with no westward flow into the Dry Valleys.

The mechanism and history of deglaciation following the late Wisconsin ice maximum in West Antarctica is a significant glacial geologic problem, involving ice thinning and grounding-line retreat of the Ross Sea ice sheet in the central and outer Ross Sea, and flotation to form the Ross Ice Shelf in the central and southern Ross Sea. McMurdo Sound is of particular importance for understanding this transition, because apparent remnants of former grounded ice are preserved as part of the MIS (Kellogg and others, 1990).

\section{GLACIAL GEOLOGY OF THE MCMURDO ICE SHELF}

The MIS is an extension of the Ross Ice Shelf that occupies southern McMurdo Sound (Stuart and Bull, 1963). It is bounded on the south by Minna Bluff, on the north by Ross Island and the seasonally open waters of McMurdo Sound, on the west by Mount Discovery and the Dry Valleys of southern Victoria Land, and on the east by the Ross Ice Shelf and White Island (Figs 1 and 2). Koettlitz Glacier flows into the MIS west of Brown Peninsula. The eastern part of the MIS is dominated by net annual surface accumulation, like the remainder of the Ross Ice Shelf, but the western part is characterized by surface ablation (Swithinbank, 1970). Prominent bands and patches of sediment debris mantle the MIS surface in this area. The following extended discussion concentrates on the western ablation area and is based largely on Kellogg and others (1990).

The MIS debris bands comprise sediment (ranging in size from clay to boulders but dominated by sand and gravel), marine biotic remains (including: siliceous sponges, molluscs, barnacles, corals, bryozoans, Foraminifera, diatoms and fish), and non-marine algae and diatoms that live in seasonal melt ponds of the MIS surface. Debenham (1919) proposed that marine sed-

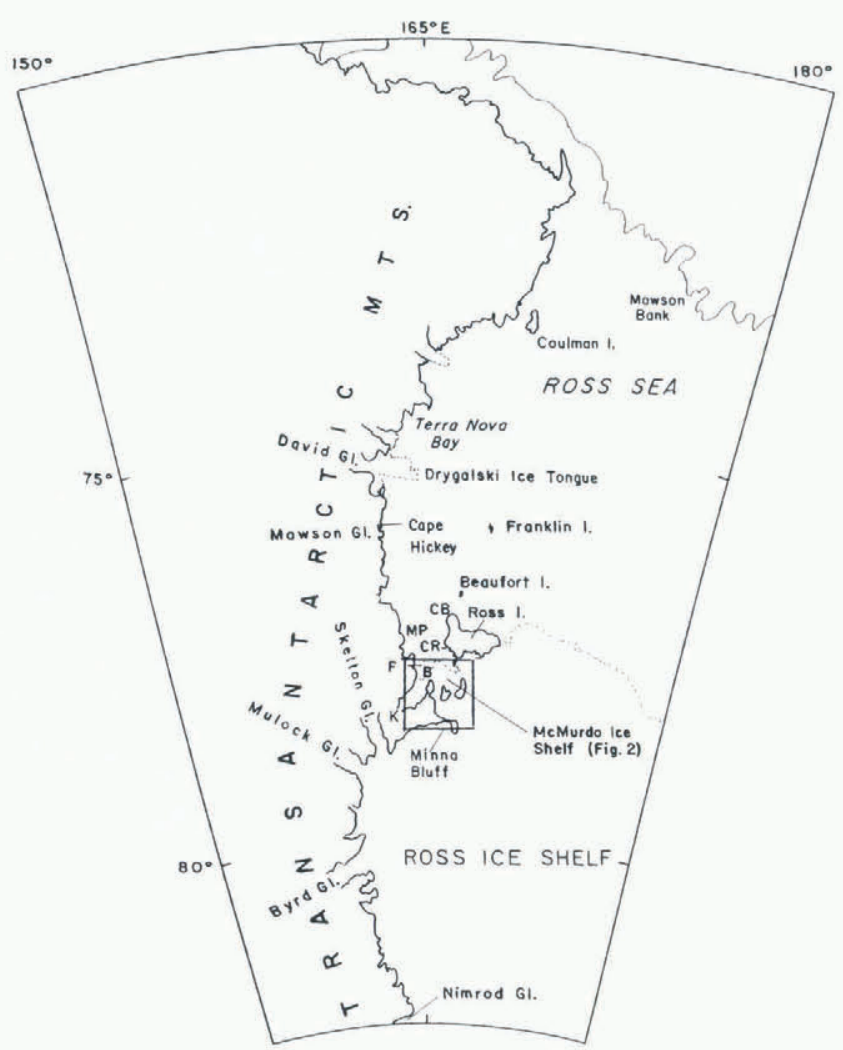

Fig. 1. Index map showing locations mentioned in text. See Figure 2 for delails of the MIS. Symbols: $B=$ Blue Glacier; $C B=$ Cape Bird; $C R=$ Cape Royds; $F=$ Ferrar Glacier; $K=$ Koettlitz Glacier; $M P=$ Marble Point.

iment and biota were incorporated into the MIS by basal adfreezing, to emerge eventually on the MIS surface because of net annual surface ablation. Subsequent workers, who have reported biotic remains on the MIS, include: Debenham, 1949, 1961; Swithinbank and others, 1961; Speden, 1962; Gow and others, 1965; Kellogg and others, 1977; Brady, 1978; Hayward and Taylor, 1984; Kellogg, 1987; Howard-Williams and others, 1989, 1990; Hart, 1990; Suren, 1990. Gow and Epstein (1972), Stuiver and others (1981b) and Kellogg and others (1990) used oxygen-isotopic analyses of MIS ice to show that lowermost Koettlitz Glacier and most ice in the surface-ablation zone formed from frozen sea water, supporting Debenham's hypothesis.

Ice-thickness data obtained by radio echo-sounding (Swithinbank, 1970) and drilling (Gow and Epstein, 1972) are shown in Figure 3. Thicknesses between Mount Discovery and Black Island and north of Minna Bluff exceed $100 \mathrm{~m}$. Further north, most thicknesses range from 20 to $50 \mathrm{~m}$. This information, together with observed surface-ablation rates $\left(0.5-1.0 \mathrm{~m}\right.$ year $^{-1}$; Gow, 1967; personal communication from A.L. DeVries, 1987), suggests that ice in the northern part of the MIS must be less than 100 years in age but the presence of fossil shells $\left({ }^{14} \mathrm{C}\right.$ ages $\leq 7750 \mathrm{BP}$; all dates in this paper are uncorrected) suggests that basal freezing and surface ablation must be nearly in equilibrium. The MIS probably did not disintegrate completely during the Holocene because ${ }^{14} \mathrm{C}$ dated shells have progressively older ages towards the north along debris bands. 


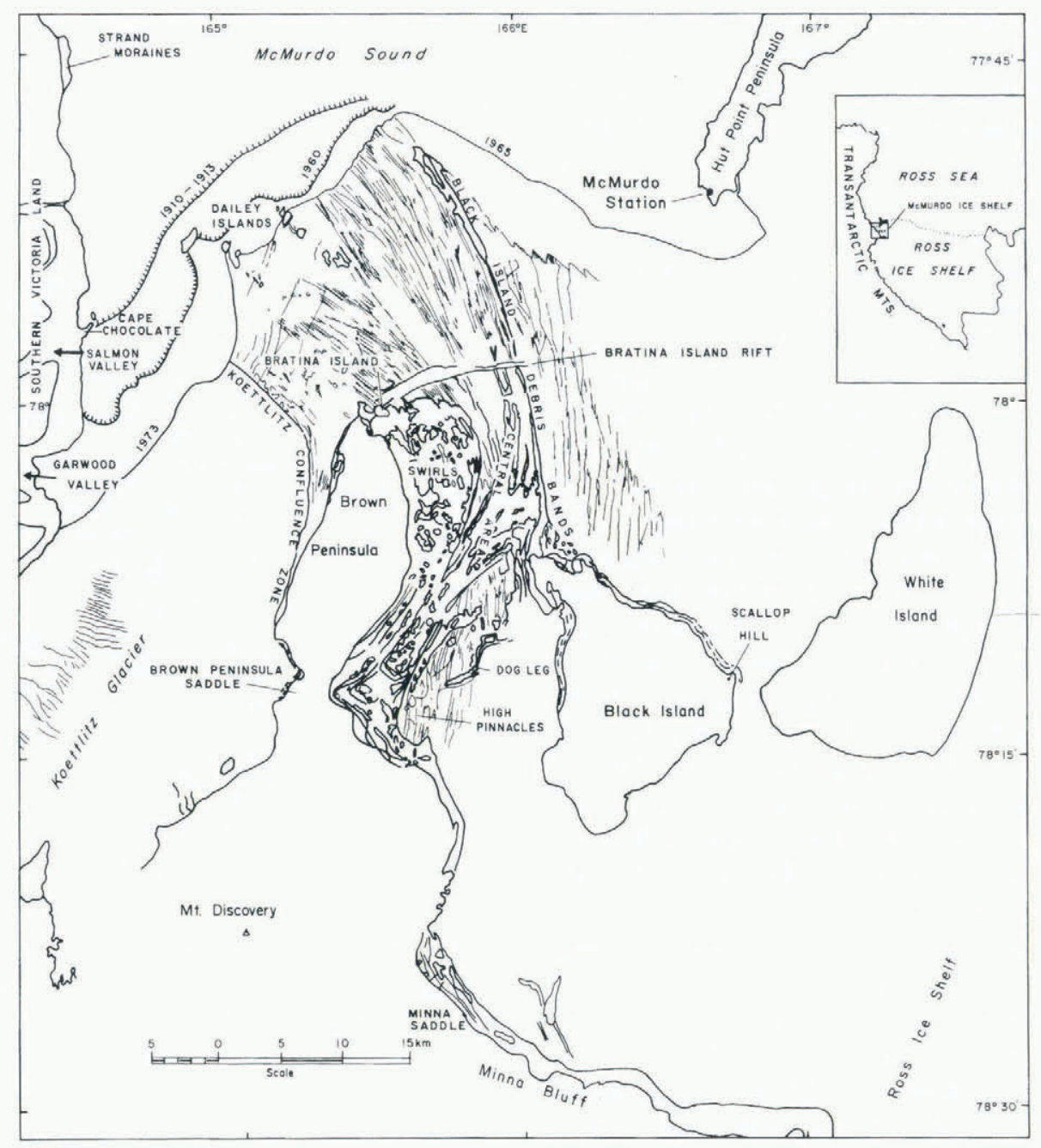

Fig. 2. McMurdo Ice Shelf (MIS) area, showing locations mentioned in text and informal names for study areas (Black Island debris bands (BIDB), "Swirls", central area, etc.). Note that because the MIS is so complex, only major debris bands and features are shown. Base map used here is modified from Stuiver and others (1981a), is based on U.S. Geological Survey topographic maps, aerial photographs and material from other sources.

Very little ice is advected today into the western MIS from the Ross Ice Shelf (Swithinbank, 1970; Bentley and others, 1979) or from Koettlitz Glacier (Gow and Epstein, 1972). Hence, the mass balance of this area is dominated by basal freezing and surface ablation, the latter caused primarily by adiabatically warmed katabatic winds flowing down on to the MIS from Minna Bluff and Mount Discovery (Stuiver and others, 1981a). Icevelocity measurements in the western MIS are less than $5 \mathrm{~m}$ year $^{-1}$ towards the north between Mount Discovery and Black Island and north of the strait between White and Black Islands (Swithinbank, 1970). Higher velocities of $18-22 \mathrm{~m} \mathrm{year}^{-1}$ directed west-northwest to northwest were recorded near the calving margin between Ross Island and the Dry Valleys (Swithinbank, 1970). Most ice movement north of Black Island is towards the north or northwest, parallel to debris bands, especially along the striking debris band extending $\sim 30 \mathrm{~km}$ from Black Island to the calving margin (Black Island debris bands: BIDB), because of the progression of ${ }^{14} \mathrm{C}$ ages mentioned above (Kellogg and others, 1990). However, an anonymous reviewer suggested that flow might have been perpendicular to debris bands, in which case debris comprising the BIDB might have originated along the coasts of Black and White Islands. This "normal flow model" permits postulation of a flow regime entirely different from that discussed above, with different locations for debris and fossil origin, and hence can have a significant bearing on interpretations of present and former ice flowlines.

Kellogg and others (1990) recognized two distinctly different types of debris bands on the MIS. The first group, discussed above, is characterized by thin (usually $<10 \mathrm{~cm}$ thick) debris overlying clean shelf ice, in which marine shells yield ${ }^{14} \mathrm{C}$ ages ranging up to $7700 \mathrm{BP}$. Ice underlying debris in this young group of debris bands usually has $\delta^{18} \mathrm{O}$ values ranging from -5.0 to $+5.0 \%$, indicating a marine origin. The presumed northward pattern of modern ice movement has been discussed above.

The second type of debris band is located primarily along the east coast of Brown Peninsula in the "Swirls" area (Fig. 2). Debris thickness here appears to exceed $10 \mathrm{~cm}$ but its full extent has not been determined, because it is ice-cemented below $5-10 \mathrm{~cm}$. A significant part of the boulders here have lithologies indicating transport from the Transantarctic Mountains. Some of the bands cross the tide crack along the MIS grounding line and extend on to the flanks of Brown Peninsula and even cross the 


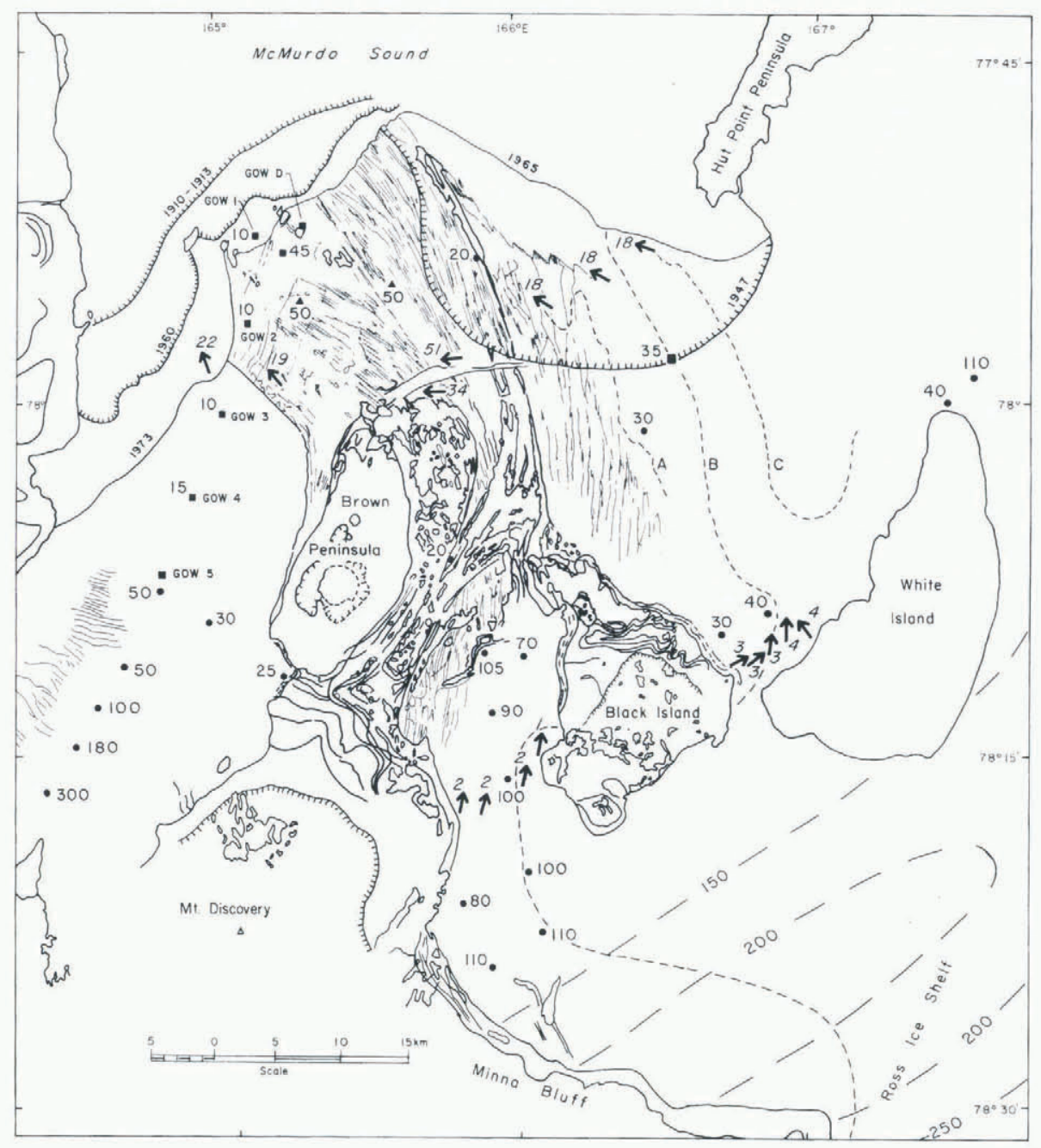

Fig. 3. McMurdo Ice Shelf thickness and ice-flow data (after Kellogg and others, 1990, fig. 17). Solid dols and arrows are thickness (in m) and velocity ( myear $^{-1}$ ) measurements (Swithinbank, 1970), respectively; solid squares are drillholes (Gow and Epstein, 1972), except $45 \mathrm{~m}$ ice depth near the easternmost Dailey Islands which was extrapolated by Zotikov and Gow (1967); solid triangles are thicknesses rounded to the nearest $5 \mathrm{~m}$ from seismic soundings (Cook, 1963); $35 \mathrm{~m}$ depth is from a drillhole through the ice shelf (Paige, 1968). Dashed contour lines north of Minna Bluff are ice thicknesses (U.S. Geological Survey, 1972). Dashed lines labeled "A", "B" and "C"' are from Swithinbank (1970). "A" marks the boundary between rough ice with melt streams and considerable relief (in the west) and much smoother bare ice. "B" approximates the surface equilibrium line and is extended into the Minna Bluff area based on our observations. See Swithinbank (1970) for significance of "C"'. Additional thickness and velocity data for the eastern part of the MIS (accumulation area) have been given by McCrae (1984). Ice-frontal position in 1947 is probably incorrect as explained by Kellogg and others (1990). Dashed lines on Brown Peninsula, Mount Discovery and Black Island are maximum extent of Ross Sea Drift (Stuiver and others, 1981a).

Brown Peninsula saddle (Stuiver and others, 1981a). Some shell dates from the northern part of the "Swirls" and adjacent bands and patches that are thought to have been former parts of the "Swirls" area yield ${ }^{14} \mathrm{C}$ ages $>20000 \mathrm{BP}$. Some ice samples from this area yield $\delta^{18} \mathrm{O}$ values ranging from -25.35 to $-48.96 \%$, suggesting the presence of patches of glacial ice that formed at elevations above $3000 \mathrm{~m}$ (Morgan, 1982) and was advected to southern McMurdo Sound. The "central" area, located between Brown Peninsula and Black Island, where thick debris is also present, may also represent relict debris bands. The sparse ${ }^{14} \mathrm{C}$ and $\delta^{18} \mathrm{O}$ data available from this area are not consistent with remnant ice but additional field work is required to test this hypothesis.

Sedimentologic, ${ }^{14} \mathrm{C}$ and $\delta^{18} \mathrm{O}$ data described above, combined with the observed pattern of debris bands, suggest that the "Swirls" area includes deformed remnants from the grounded late Wisconsin Ross Sea ice sheet. Glacial flow was apparently directed from east to west across southern McMurdo Sound, with an ablating margin pushing into the mouths of the Dry Valleys to the west (Fig. 4). The distribution of late Wisconsin-aged Ross Sea drift on Black Island and Brown Peninsula suggests that high peaks protruded through the ice sheet as nunataks (Stuiver and others, 1981a); Black and White Islands, and Brown Peninsula, probably served as effective barriers, retarding flow rates. Debris entrained in the grounded ice probably accumulated on the surface in the McMurdo Sound ablation area, producing some of the debris bands now preserved in the "Swirls", because the prevailing surface-ablation regime here (Stuiver and others, 1981a) resulted in upward-directed ice flowlines. This concludes our summary of previous work on the MIS (Kellogg and 


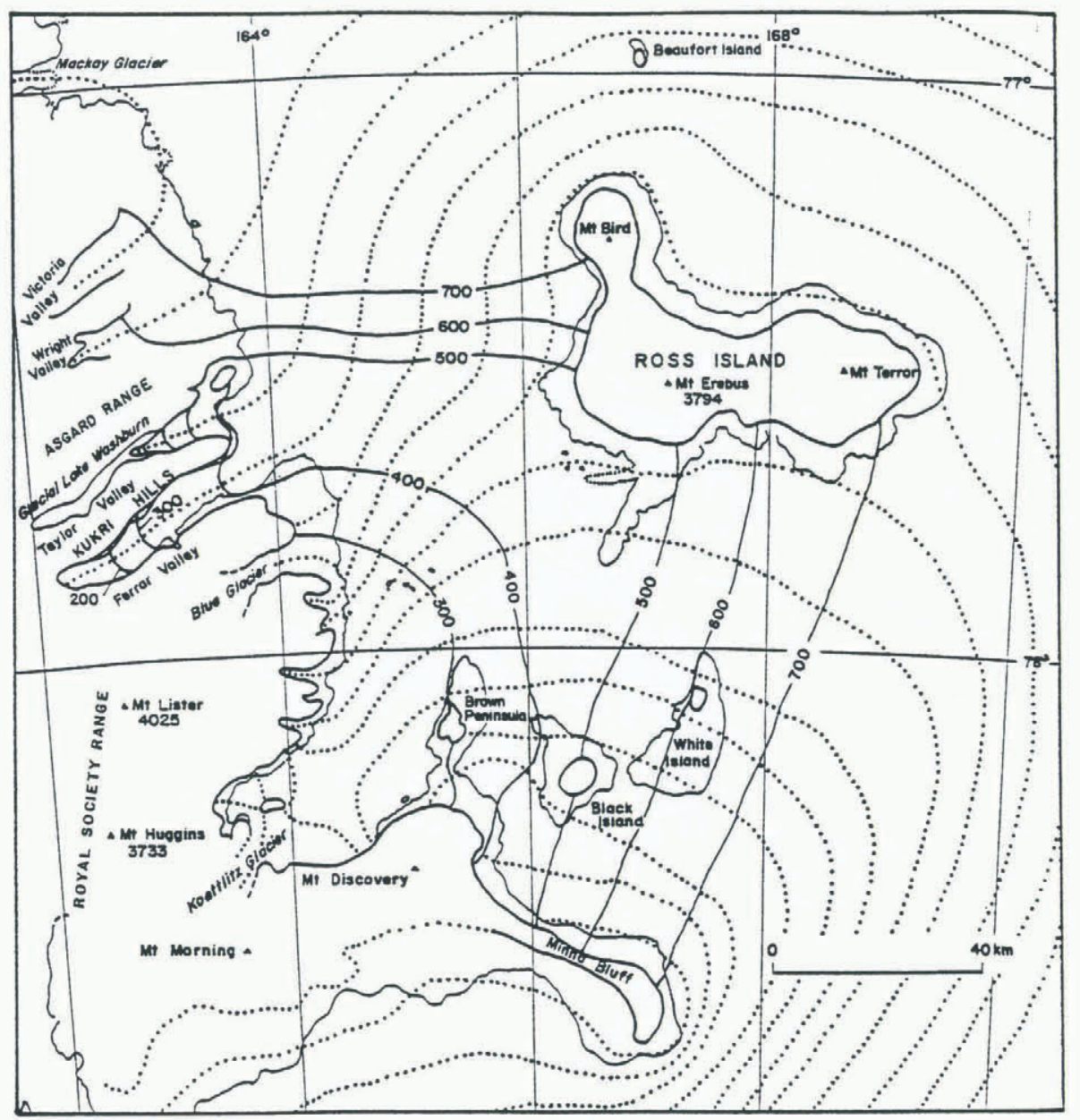

Fig. 4. Surface contours (solid lines; elevations in m a.s.l.) and flowlines (dotted) of the late Wisconsin Ross Sea ice sheet in McMurdo Sound (after Stuiver and others, 1981a, fig. 7-16).

others, 1990).

We turn now to a discussion of possible ramifications of MIS and other geologic data for recognizing West Antarctic ice retreat. Grounded ice covered most of the Ross Sea continental shelf during the late Wisconsin maximum, as discussed later in this paper (Fig. 7). Deglaciation to the present configuration, with the floating Ross Ice Shelf covering the southern half of the Ross Sea, probably involved glacial thinning and ungrounding. We should be able to recognize two events at any particular location north of the present ice-shelf front: the times when (1) the grounding line and (2) the calving ice-shelf margin retreated past the location. In principle, ${ }^{14} \mathrm{C}$ dating of basal postglacial sediments in Ross Sea cores should provide a detailed picture of grounding-line recession. This has not proved possible with conventional ${ }^{14} \mathrm{C}$ dating because Ross Sea sediments have a low organic carbon content and calcareous shells are rare, and few AMS dates have been obtained. However, ${ }^{14} \mathrm{C}$ dates from the MIS also provide limits on the timing of grounding-line recession. All these dates are either $>20000 \mathrm{BP}$ or $<7750 \mathrm{BP}$. If the absence of dates between these ages represents the time when grounded ice filled southern McMurdo Sound, the younger population of dates records events following thinning, grounding-line recession and the incursion of marine waters beneath the MIS. The older population provides minimum dates for preglacial marine conditions. Thus, the grounding line had receded to the vicinity of Brown Peninsula saddle by $7750 \mathrm{BP}$

Calving-margin recession may be tracked using ${ }^{14} \mathrm{C}$ dated raised beaches, which require seasonal open water to form. Stuiver and others (1981a) dated numerous raised beaches along the Ross Sea coast and offlying islands, and concluded that the calving margin extended from Marble Point to a position north of Beaufort and Franklin Islands shortly before $5650{ }^{14} \mathrm{CBP}$ and had retreated to a position from Cape Bernacchi to near Mount Bird on Ross Island shortly after $5650{ }^{14} \mathrm{C}$ BP. The first observations of the MIS during Scott's 1910-13 expedition showed the western part of the calving margin extending from Cape Chocolate to near the present terminus of the Black Island debris band; the eastern part was much like today. Calving-margin retreat since 1910 13 has occurred primarily in this western section.

During the period from the LGM to about $7750 \mathrm{BP}$, thinning probably continued to concentrate englacial debris at the surface in southern McMurdo Sound. In addition, as the ice wasted, exposing more and more of Black and White Islands and Brown Peninsula, the iceflow pattern changed. The former east-to-west pattern was probably replaced by nearly stagnant conditions or sluggish northward movement (on the order of a few $\mathrm{m}$ year ${ }^{-1}$ ) between the islands and Brown Peninsula, and existing debris bands were probably deformed or bent into the shapes that give the "Swirls" area its name. 
Kellogg and others (1990) postulated that while most of the remainder of the MIS became progressively afloat, the "Swirls" remained grounded, because it rested on a wide shallow shelf east of Brown Peninsula and that ungrounding here is a very recent event.

\section{GLACIOLOGICAL RECONSTRUCTIONS}

Ice elevations and flowlines for our glaciological reconstructions are based on data for the area between $150^{\circ} \mathrm{E}$ and $180^{\circ}$ and from $70^{\circ}$ to $83^{\circ} \mathrm{S}$ (Fig. 1), that is, the Transantarctic Mountains from northern Victoria Land south to near Nimrod Glacier and adjacent areas of East and West Antarctica. We reconstructed ice flowlines and ice elevations in this sector to conform with these field data, not with a theoretically based computer ice-sheet model. Figure 5 shows the bedrock topography for the modern ice sheet (Drewry, 1983) that constrains our reconstructions.

The modern ice-sheet profile (Fig. 6) and the LGM reconstruction (Fig. 7) represent two end members in our series of reconstructions. They are constrained by observational data and/or a wealth of glacial geologic

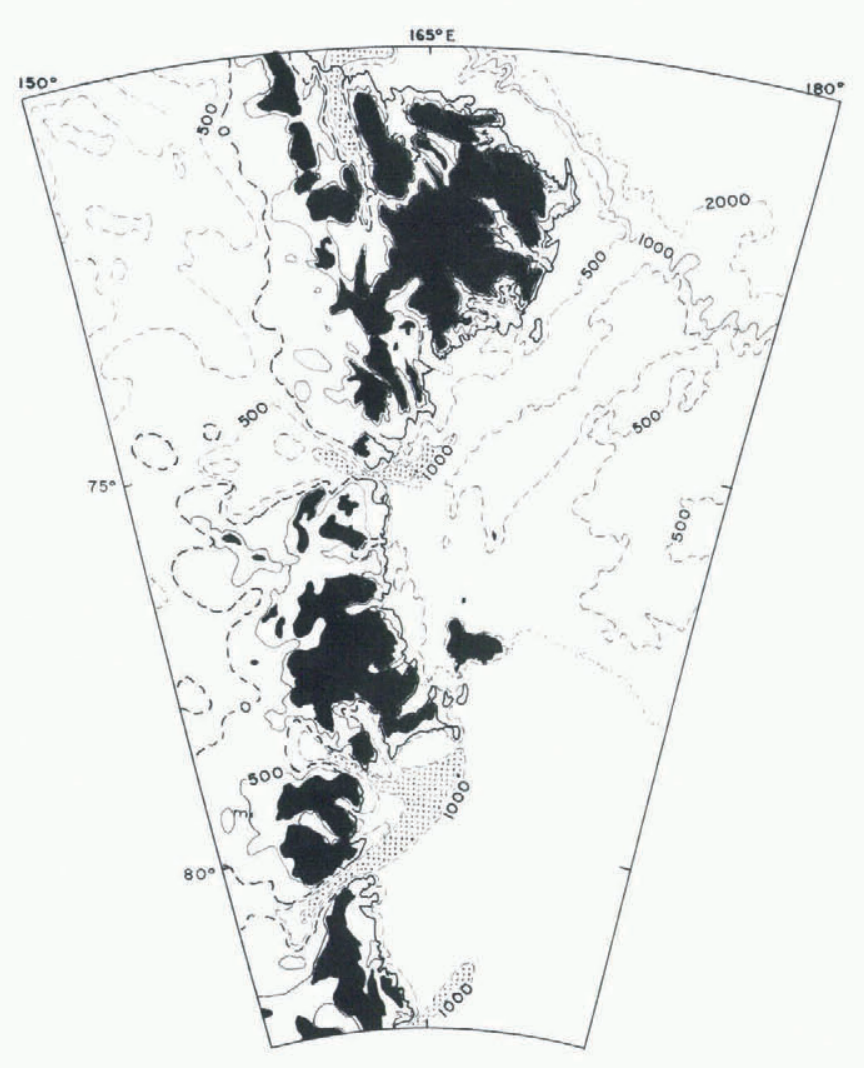

Fig. 5. Modern subglacial topography (after Drewry, 1983), contoured at $500 \mathrm{~m}$ intervals. Present sea level is shown by a heavy solid line where not covered by the ice sheet, and elsewhere by a heavy dashed line. Solid pattern indicates elevations above $1000 \mathrm{~m}$; stippled pattern indicates depths greater than $1000 \mathrm{~m}$. Note that these great depths are restricted to outlet-glacier troughs now occupied by Byrd, Mulock, David and Rennick Glaciers. Present northern margin of the Ross Ice shelf is indicated by a light dashed line.

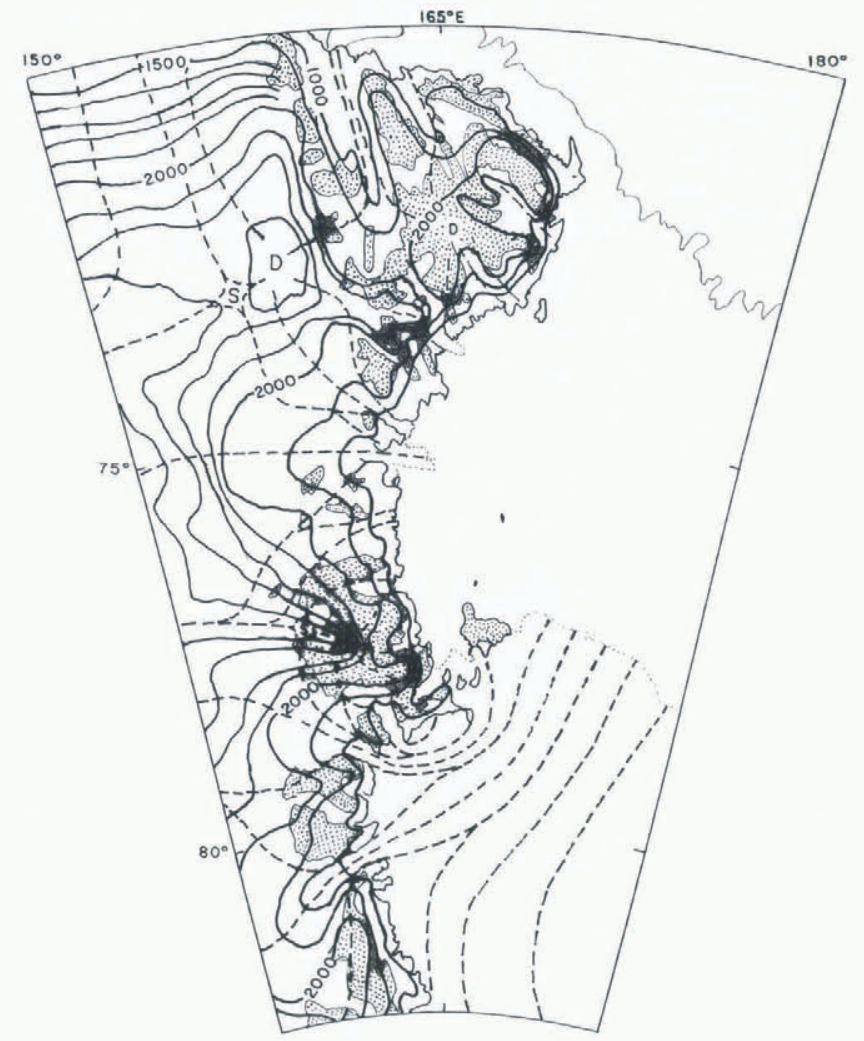

Fig. 6. Present-day ice elevations (after Drewry, 1983) contoured at 500, 1000 and at $100 \mathrm{~m}$ intervals above $2000 \mathrm{~m}$. Flowlines indicated by dashed lines. " $D$ " = ice dome; " $S "=$ ice saddle. Stippled pattern indicates bedrock elevations above $1000 \mathrm{~m}$. Note the prominent dome west of northern Victoria Land. A smaller dome (Taylor Dome - not labeled) is situated west of McMurdo Sound. Flow from Taylor Dome is down Skelton Glacier but terminates south of Minna Bluff. Flow from Mulock Glacier rounds Minna Bluff with most ice passing east of Ross Island.

information collected along the Victoria Land coast and on offlying islands (e.g. Denton and others, 1971, 1989; Stuiver and others, $1981 \mathrm{a}, \mathrm{b}$; Kellogg and others, 1990; Baroni and Orombelli, 1991, 1994; Dochat, 1994) including ages and elevations of Ross Sea drift and raised beaches, and locations of kenyite erratics. These data help to constrain LGM ice elevations along the coast of Victoria Land and in some cases suggest former flow directions. More geologic data from the Ross Sea would be highly desirable to refine our work but are currently unavailable. Our reconstructions for 16 000, 12000,8000 and 4000 BP (Figs 9-12) are less rigorous. They represent sequential modifications of the LGM reconstruction constrained by the limited available glacial geologic data.

\section{Modern ice-flow regime}

One objective of our work is to develop a model of the dynamics of the modern MIS ice-flow regime. Of particular importance is ice advected into the MIS area, because ice derived from precipitation outside the immediate area may be expected to display different stable-isotope compositions and carry exotic erratic 


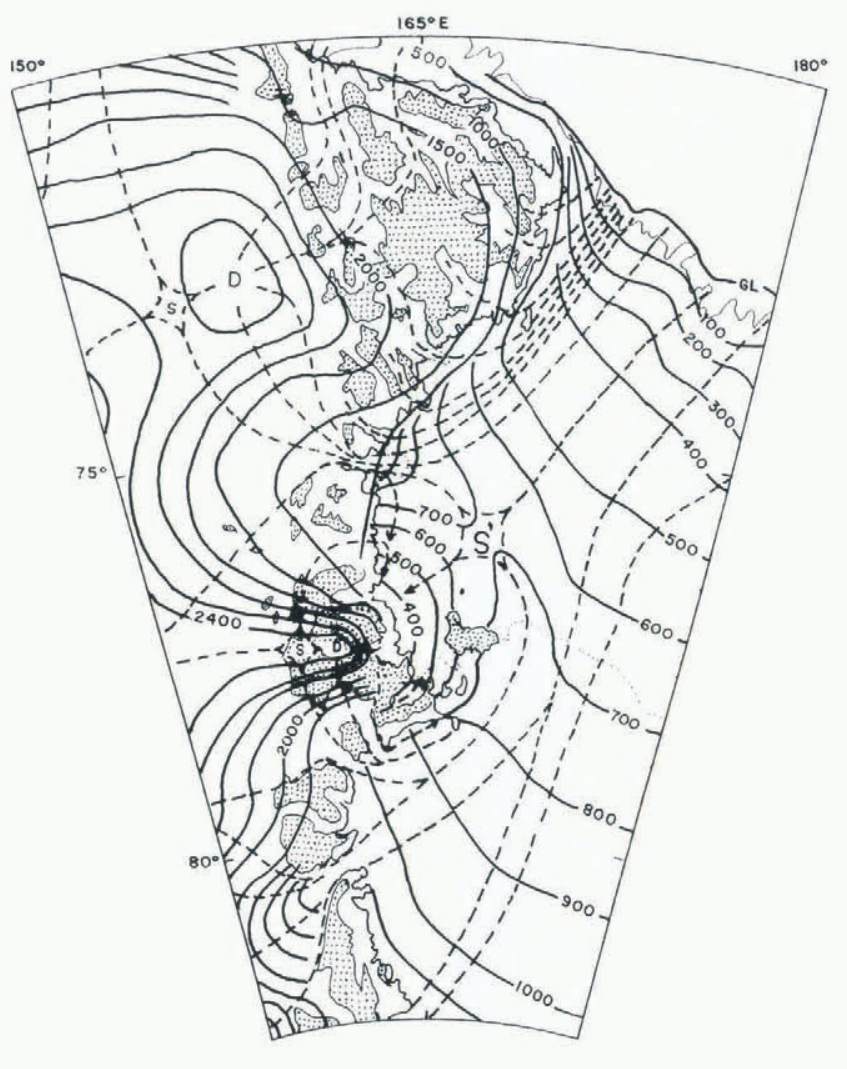

Fig. 7. LGM ice-sheet reconstruction contoured at $100 \mathrm{~m}$ intervals (solid lines). "GL" = grounding line; other symbols and patterns as in Figure 6. Note the similarity of ice elevations west of the Transantarctic Mountains to modern conditions. Major differences are in West Antarctica where a low-profile ice sheet occupied the entire Ross Sea. The prominent saddle north of Ross Island permitted southward ice flow into McMurdo Sound, consistent with the Stuiver and others (1981a) reconstruction. Flow from Taylor Dome (west of McMurdo Sound) was down Skelton Glacier but terminated south of Minna Bluff. Flow from Mulock Glacier rounded Minna Bluff and Ross Island before flowing south into McMurdo Sound.

debris. MIS features which are not accounted for by the modern flow regime can be assumed to be relict, especially if the $\delta^{18} \mathrm{O}$ of ice in these areas has the signature of ice formed by precipitation at high elevations on the East Antarctic ice sheet (e.g. the "Swirls" and possibly the central area). Knowledge of the modern flow regime permits us to test and evaluate conflicting hypotheses about grounded ice extent in the Ross Sea during the last glacial maximum (e.g. Drewry, 1979; Stuiver and others, 1981a).

Modern ice elevations (Drewry, 1983) were used to construct ice flowlines for the East Antarctic ice sheet (Fig. 6). Three prominent domes are located in the study area: Talos Dome in northern Victoria Land, Dome Circe west of northern Victoria Land and Taylor Dome west of the Dry Valleys area. East Antarctic ice is discharged through the Transantarctic Mountains at a number of locations (notably Byrd, Mulock and David Glaciers), all of which coincide with deep bedrock troughs (Fig. 5). North of McMurdo Sound and Ross Island, this discharge is more or less directly into the sea, and the ice is removed as floating icebergs. However, south of Ross Island, the East Antarctic discharge feeds the floating Ross Ice Shelf where it is supplemented by local precipitation. These two sources of ice are balanced by bottom melting and calving from the ice-shelf front, at least in historic time. An exception is the western part of the MIS where a peculiar combination of basal adfreezing, surface ablation and calving-margin retreat have been observed as discussed above. Flowlines shown for the Ross Ice Shelf are consistent with observed flow directions (Swithinbank, 1970, personal communication; U.S. Geological Survey, 1972).

Possible contributions of ice advected to McMurdo Sound can be related to different possible precipitation sources and or ice-elevation fluctuations: (1) Koettlitz Glacier, representing local precipitation in southern Victoria Land, (2) Skelton Glacier, representing mostly local precipitation and precipitation further west on the flank of the East Antarctic ice sheet, and (3) Mulock Glacier, representing a nearly pure high-elevation East Antarctic precipitation source. We combine model results with $\delta^{18} \mathrm{O}$ analyses of MIS ice, ${ }^{14} \mathrm{C}$ dates on MIS shells and MIS boulder-provenance data to evaluate the ways in which this ice-supply pattern changed in the past, during (Fig. 7) and since the LGM (Figs 9-12). This analysis helps to detail the deglacial transition from the grounded Ross Sea ice sheet to shelf ice and may permit a closer correlation of late Quaternary Dry Valleys and Ross Sea sediment records.

We made some preliminary measurements and calculations for the modern Skelton and Mulock Glaciers drainage basins and the Ross Ice Shelf adjacent to the MIS to supplement the glaciologic model results in the preparation of our LGM reconstruction. Using Drewry's (1983) surface-elevation data, we plotted surface flowlines to determine the Mulock Glacier catchment area. This catchment was subdivided into $1550 \mathrm{~km}$ wide sectors, for each of which we measured area. The total catchment area is $\sim 95000 \mathrm{~km}^{2}$. We were unable to do a similar analysis for Skelton Glacier, because the drainage area is so small on Drewry's (1983) map and so cluttered with Transantarctic Mountains topography and flight lines that we could not discern surface-elevation contours. Hence, we estimated a total catchment area for Skelton Glacier of $\sim 10000 \mathrm{~km}^{2}$, a value that we believe overestimates the true area. Using surface mass-balance data (Giovinetto and others, 1989, fig. 2), we assigned massbalance rates $\left(\mathrm{kg} \mathrm{m}^{-2}\right.$ year $\left.{ }^{-1}\right)$ to each sector to calculate net accumulation. The total calculated for Mulock Glacier is $\sim 8.5 \times 10^{8} \mathrm{~kg}$ year $^{-1}$ and that for Skelton Glacier is $\sim 1.5 \times 10^{8} \mathrm{~kg}^{-1} \mathrm{yr}^{-1}$. The total flux through the Transantarctic Mountains was calculated for each glacier using a density of $0.9 \mathrm{Mg} \mathrm{m}^{-3}$. Total fluxes are $\sim 9.5 \times 10^{5} \mathrm{~m}^{3}$ year $^{-1}$ for Mulock Glacier and $\sim 1.6 \times 10^{5}$ $\mathrm{m}^{3}$ year $^{-1}$ for Skelton Glacier. In both cases, this volume of ice passes through a narrow channel approximately $10 \mathrm{~km}$ wide on to the Ross Ice Shelf. Grounding-line ice thicknesses are approximately 1000 and $850 \mathrm{~m}$, respectively (Fig. 5).

Ice discharged from Skelton and Mulock Glaciers today becomes afloat as it passes through the Transantarctic Mountains. Thickness data for the Ross Ice 
Shelf (U.S. Geological Survey, 1972) show a complicated pattern related to the numerous ice streams, like Skelton, Mulock and Byrd Glaciers, but there is a general thinning from values close to $500 \mathrm{~m}$ where ice streams enter the ice shelf to less than $300 \mathrm{~m}$ near the calving margin. This pattern is complicated by surface accumulation and by basal melting, which is apparently very important within $\sim 200 \mathrm{~km}$ of the calving margin (except beneath the western MIS) and which causes much of the noted thinning.

Tracing individual ice-stream components to the iceshelf margin is not trivial because of these complex interactions. What is clear from the U.S. Geological Survey (1972) thickness data is that ice rounding Minna Bluff and flowing west between Minna Bluff and White Island today is not derived from Skelton Glacier but from Mulock Glacier and from local precipitation off Minna Bluff. Swithinbank (1970, personal communication) believed that this flow is negligible today, with most Ross Ice Shelf ice passing east of White Island and Ross Island. Our analysis supports this view (Fig. 8a). Assuming that the Skelton Glacier ice-flow band is $20 \mathrm{~km}$ wide, its area is approximately one-third that of the catchment area. Modest basal melting rates, on the order of $10 \mathrm{~cm}_{\text {year }}{ }^{-1}$, should remove all the glacial ice before it rounds Minna Bluff. In any case, Skelton Glacier ice could not explain the scattered large negative $\delta^{18} \mathrm{O}$ values from the MIS, because the catchment area for this glacier is below $2500 \mathrm{~m}$. In contrast, the Mulock Glacier catchment area extends well up on to the East Antarctic ice sheet (EAIS) to elevations over $3000 \mathrm{~m}$. Most Mulock

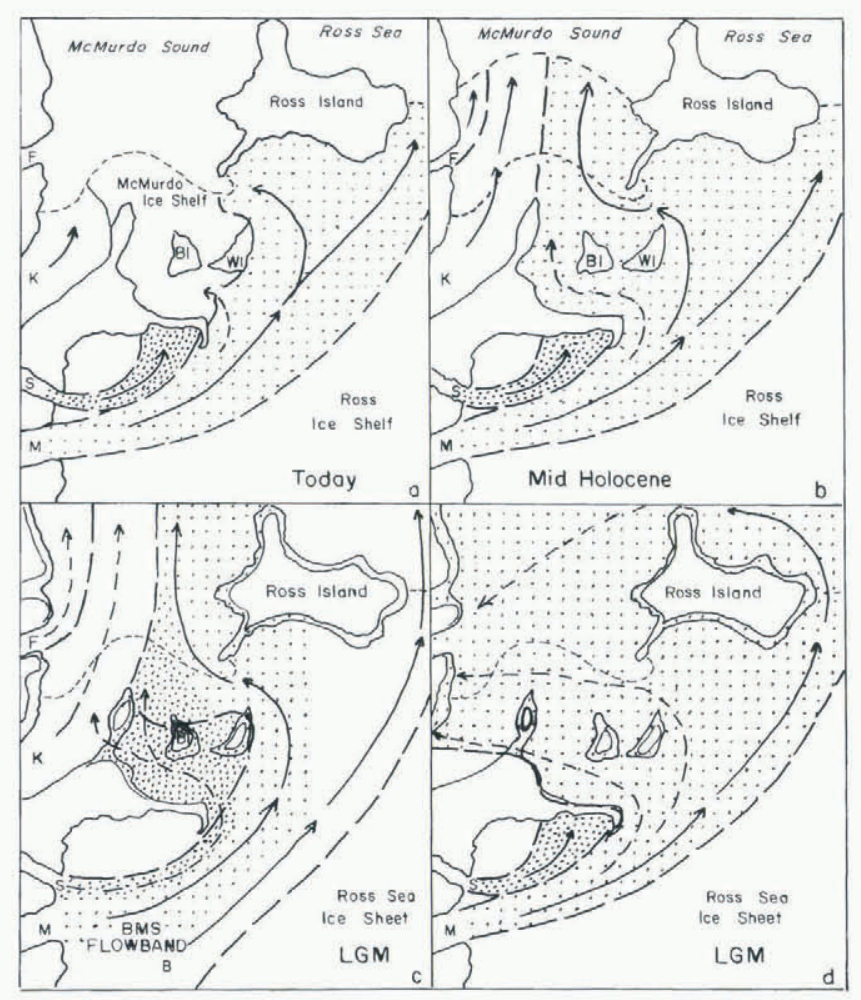

Fig. 8. Cartoons illustrating different ice-flow patterns in McMurdo Sound: $a$. Modern ice-flow regime; $b$. MidHolocene (4000-8000 BP), c. LGM modified from Drewry (1979), d. LGM modified from Stuiver and others (1981a).
Glacier ice apparently either melts off the base of the Ross Ice Shelf or flows east of Minna Bluff and Ross Island to calve into the Ross Sea. This analysis demonstrates that the MIS ice samples with high negative $\delta^{18} \mathrm{O}$ values cannot be related to the modern flow regime.

Koettlitz Glacier today contributes ice only to the area west of Brown Peninsula, and even here, ice formed by precipitation in the local catchment area of southern Victoria Land mostly melts off the base of the glacier soon after it becomes afloat, so that the lower reaches are formed from frozen sea water (Gow and Epstein, 1972). Stuiver and others (1981a) suggested that Koettlitz Glacier is probably near its maximum extent today, and was even less advanced during the LGM. However, Koettlitz Glacier may have contributed more ice to the MIS during the Holocene (Fig. 8b), especially if the Ross Sea then was more open and hence a more important precipitation source than today (e.g. Kellogg and others, 1979).

\section{Last glacial maximum (LGM)}

The LGM reconstruction is presented in Figure 7. West of the Transantarctic Mountains in East Antarctica, icesheet elevations were little different from those of today (cf. Figs 6 and 7). The major differences were in West Antarctica where the Ross Ice Shelf grounded and expanded to fill most of the Ross Sea embayment. The position of the grounded margin on the Ross Sea continental shelf is problematic. We show grounded LGM ice extending to the shelf break in contrast to recent interpretations by Denton and others (1989), Anderson and others (1992) and Shipp and Anderson (1994). Anderson and others (1992) suggested that the grounding line in the westernmost trough in the northwestern Ross Sea could be established by the presence of basal tills in sediment cores. Such tills were not found in cores collected from just north of Coulman Island to the shelf break but were widespread over the remainder of the continental shelf. Radiocarbon dates from a core at the shelf break north of Coulman Island yielded ages of $>35510 \mathrm{BP}$ and about $17390 \mathrm{BP}$ (reported as corrected by -1200 year). We note that the trough extending southward from this location and past the east side of Coulman Island has a shallow sill at its outer (northern) end and a second sill occurs off Coulman Island. This trough is similar to many other continental shelf troughs in highlatitude regions, displaying foredeepening which is often attributed to modification by grounded ice. For this reason, we believe the LGM grounding line at $\sim 22000$ BP was probably located at the shelf break. This maximum position probably was not maintained for long, because sea level rose by 10-20 m by 17000 BP (Fairbanks, 1989; Blanchon and Shaw, 1995), allowing for grounding-line retreat to the position just north of Coulman Island. An alternative explanation is that the LGM grounding line was located just north of Coulman Island, slightly beyond the position we show in our $16000 \mathrm{BP}$ reconstruction, and the foredeepened outer part of this trough dates from some earlier glaciation. In either case, grounded ice in the Ross Sea sector probably had a low surface profile, rising to elevations near $1000 \mathrm{~m}$ only close to the present coast and well south of Minna Bluff. A prominent saddle is 
shown north of Ross Island at the LGM (and at $16000 \mathrm{BP})$ to divert ice flow southward into McMurdo Sound, consistent with glacial geologic evidence, especially the distribution of kenyite erratics in the Dry Valleys (Stuiver and others, 1981a).

Figure $8 \mathrm{c}$ and d shows two conflicting LGM reconstructions for the McMurdo Sound area, one based on Drewry (1979; Fig. 8c) and one based on Stuiver and others, (1981a; Fig. 8d). Drewry suggested that grounded ice did not cover much of the Ross Sea continental shelf but that the Ross Ice Shelf grounding line and calving margin advanced northward and local grounding occurred on topographic highs. One of these highs was occupied by the "Byrd-Mulock-Skelton" (BMS) flow band. He showed a branch of this flow band, consisting of ice from Skelton and Mulock Glaciers, turning westward between White and Ross Islands (but not between Minna Bluff and White and Black Islands) and northward into McMurdo Sound. Drewry stated that ice in McMurdo Sound was grounded and that it merged with ice from Koettlitz, Ferrar and Blue Glaciers. Presumably, no ablation occurred along the BMS flow band before the lobe branched off into McMurdo Sound but, rather, precipitation on this grounded ice probably caused the northward decreasing surface slope to be less than if ablation had occurred. Drewry was not specific on this point but presumably McMurdo Sound was an ablation zone (Stuiver and others, 1981a). Because the grounded ice here was through-flowing rather than terminating as in the Stuiver and others' (1981a) reconstruction (Fig. 8d) and because Drewry was not specific on the source of this ice (from Skelton and Mulock Glaciers, or from Skelton, Mulock and Byrd Glaciers?), we can only guess at ablation rates. Only one of our three MIS ice samples with high negative $\delta^{18} \mathrm{O}$ values (north of Brown Peninsula) can be explained by the Drewry (1979) model. The two other samples occur off the north shore of Minna Bluff and in the strait between White and Black Islands. Thus, our existing stable-isotope data appear to be inconsistent with Drewry's (1979) reconstruction, as do our numerous data on boulders derived from the Transantarctic Mountains that occur on MIS debris bands north of Minna Bluff and east of Brown Peninsula saddle.

Our preferred interpretation for ice flow during the LGM (Fig. 8d) is based on Stuiver and others (1981a) (see also Figure 7). According to this model, Koettlitz Glacier withdrew behind its present limit, grounded Skelton Glacier ice ablated south of Minna Bluff and Mulock Glacier ice formed two grounded lobes: one turning westward south of Ross Island and the other passing east of Ross Island to turn back toward the west and southwest, filling McMurdo Sound. Stuiver and others (1981a) suggested that the area west of White Island was probably a surface-ablation zone, ice loss being caused largely by sublimation rather than melting. Surface ablation probably also dominated the mass balance of the area south of Minna Bluff, as it does today. Ice at the LGM did not overtop Minna Bluff (Stuiver and others, 1981a). This area, fed by Skelton Glacier, has an area of about $3000 \mathrm{~km}^{2}$, approximately one-third of the present Skelton Glacier accumulation area. The accumulation rate in the Skelton Glacier catchment area today is about $150 \mathrm{~kg} \mathrm{~m}^{-2}$ year ${ }^{-1}$ but would have been even less during the last glacial maximum, when the nearest precipitation source was located north of the continental shelf break. Very modest sublimation rates could easily have balanced the flow from Skelton Glacier, as they do today. The case for Mulock Glacier ice is similar. The area of McMurdo Sound is only about $5500 \mathrm{~km}^{2}$, compared with $95000 \mathrm{~km}^{2}$ for the Mulock Glacier catchment area. Hence, Mulock Glacier ice could have filled this area easily and perhaps most of the region north to David Glacier, and still have maintained ablation rates sufficient to balance the average accumulation rate of $\sim 500 \mathrm{~kg} \mathrm{~m}^{-2}$ year $^{-1}$ in the modern catchment area.

\section{$16000 \mathrm{BP}$}

Our reconstruction for $16000 \mathrm{BP}$ (Fig. 9) is based on the LGM reconstruction (Fig. 7) modified by grounding-line retreat to the vicinity of Coulman Island (Fig. 8), which occurred by about $17000 \mathrm{BP}$ (Anderson and others, 1992). Grounding-line recession occurred most rapidly in deep troughs on the continental shelf (Fig. 5) so that the grounding line took on a wavy character, retaining a more northerly position on intervening topographic

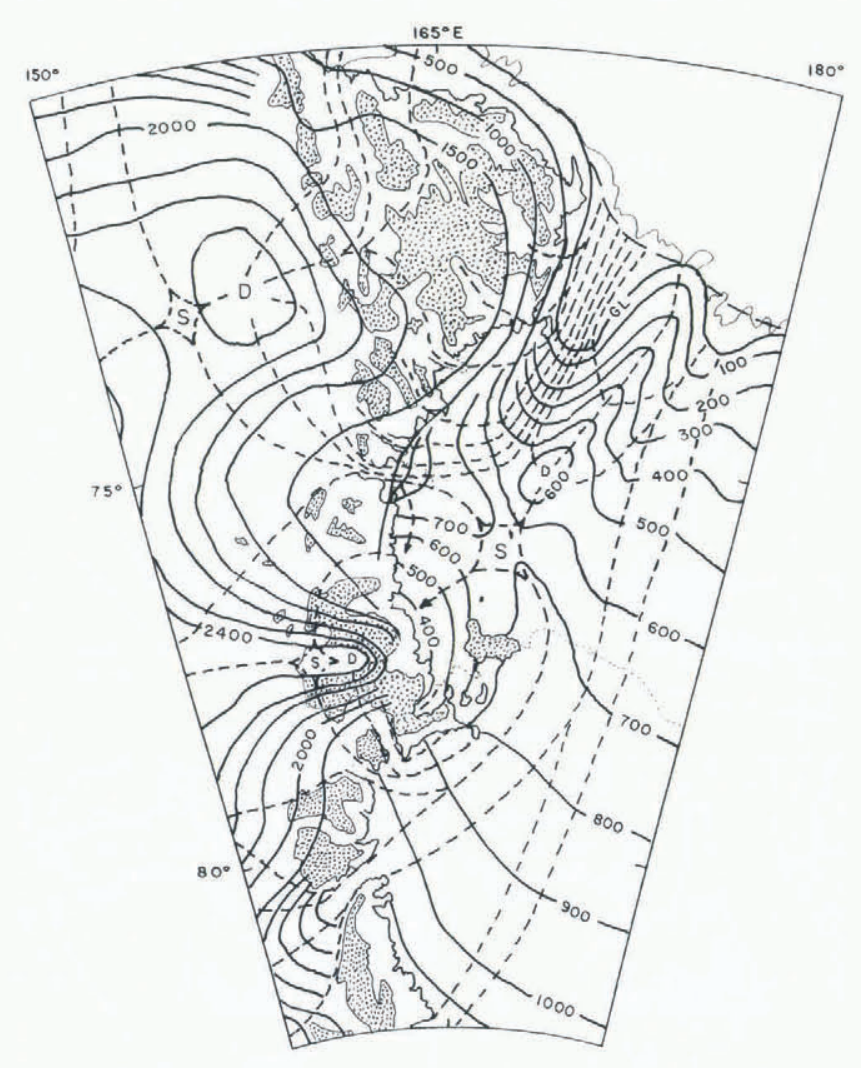

Fig. 9. 16000 BP ice-sheet reconstruction. Symbols, patterns and contours as in Figure 7. The grounding line has retreated from the continental shelf break, with deep embayments in troughs on the Ross Sea continental shelf, especially north of Coulman Island. An ice shelf still covers much of the northern part of the continental shelf. As discussed in the text, this reconstruction might represent the $L G M$, if the true LGM grounding line was just north of Coulman Island. 
highs. The saddle north of Ross Island at the LGM probably existed until after $16000 \mathrm{BP}$.

\section{$12000 \mathrm{BP}$}

By $12000 \mathrm{BP}$, the grounding line had retreated from the outer Ross Sea continental shelf to a position near Cape Hickey (Fig. 10). Radiocarbon-dated penguin remains from Cape Hickey (near Mawson Glacier) show the presence of open water by $10824 \mathrm{BP}$ (Baroni and Orombelli, 1994). Grounded ice on topographic highs in the Ross Sea, such as Mawson Bank, became the loci for small ice domes, one of which extended northward from Ross Island, replacing the LGM saddle that had

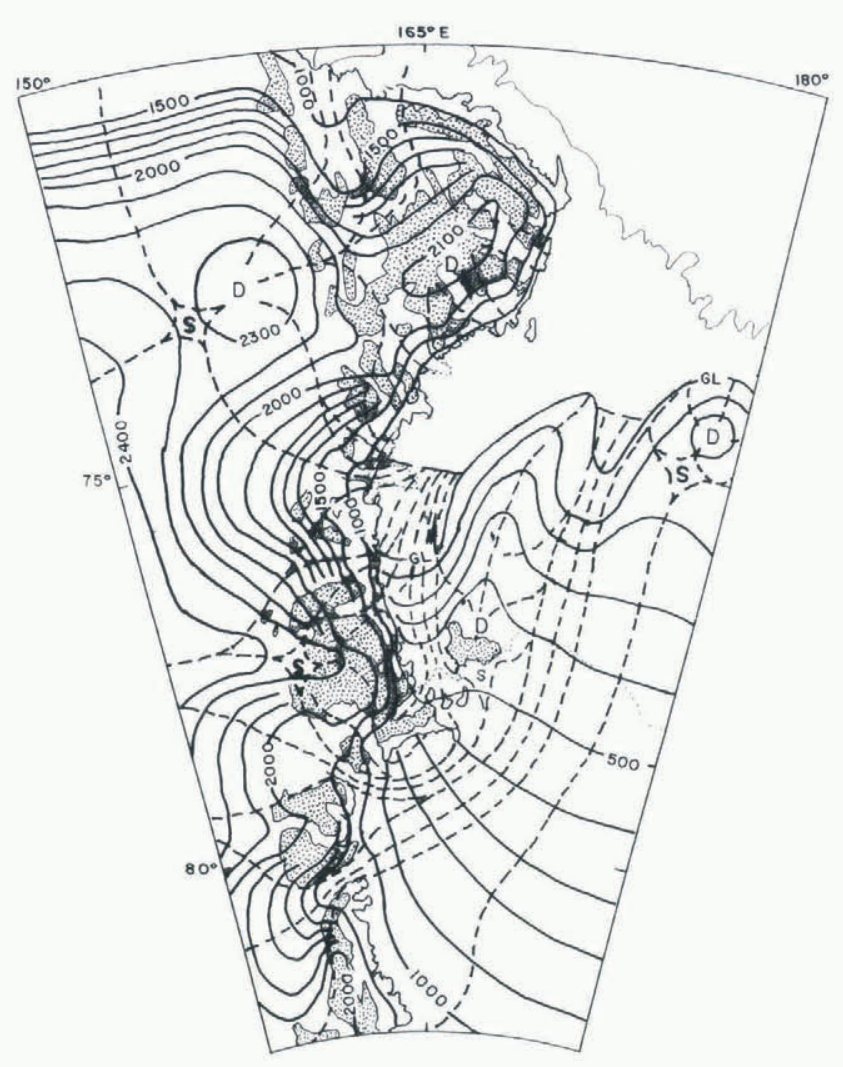

Fig. 10. 12000 BP ice-sheet reconstruction. Symbols, patterns and contours as in Figure 7. The grounding line adjacent to northern Victoria Land has retreated to the vicinity of Cape Hickey and a small ice shelf occupies this embayment north to Drygalski Ice Tongue. Note that the LGM saddle north of Ross Island has been replaced by a dome, hence ice flow through McMurdo Sound (mostly from Mulock and Koettlitz Glaciers) is now northward.

been located here. The grounding line apparently intersected the coast somewhat south of Cape Hickey (Krissek, 1988; Reid, 1989; Baroni and Orombelli, 1991). An ice shelf is shown occupying part of the area from Cape Hickey to Drygalski Ice Tongue. This ice shelf was probably not very extensive, because an active penguin rookery existed at Cape Hickey by 10824 BP, suggesting nearby open water.

The change from a saddle north of Ross Island at the LGM and $16000 \mathrm{BP}$ to a dome at $12000 \mathrm{BP}$ necessitated a major change in ice flow in McMurdo Sound and north to near Mawson Glacier. Instead of southward flow (of Mulock Glacier ice) into McMurdo Sound, the area was occupied by northward through-flow of Mulock Glacier ice with contributions from Koettlitz, Blue and Ferrar Glaciers. This pattern bears a striking similarity to Drewry's LGM reconstruction (cf. Fig. 10 with Fig. 8b and $\mathrm{c}$ ).

\section{BP}

The $8000 \mathrm{BP}$ reconstruction (Fig. 11) traces the grounding-line recession even further south into the Ross Sea. The oldest reported postglacial marine fossils at Cape Bird are slightly older than $8000 \mathrm{BP}$ (Speir and Cowling, 1984; Heine and Speir, 1989; Dochat, 1994) and 7750 BP at Mount Discovery (Kellogg and others, 1990). Hence, marine waters penetrated to these locations by about $8000 \mathrm{BP}$ as the grounding line retreated. We show the grounding line extending from Mount Discovery-Black Island-White Island-Ross Island and continuing to the east in about the same position as the modern calving margin. The ice-shelf front also probably receded but was located well north of Cape Bird, because the oldest raised beaches there are dated at 4885 BP (Dochat, 1994). The ice-front position shown is poorly constrained. We show two small ice rises in the vicinity of Beaufort and Franklin

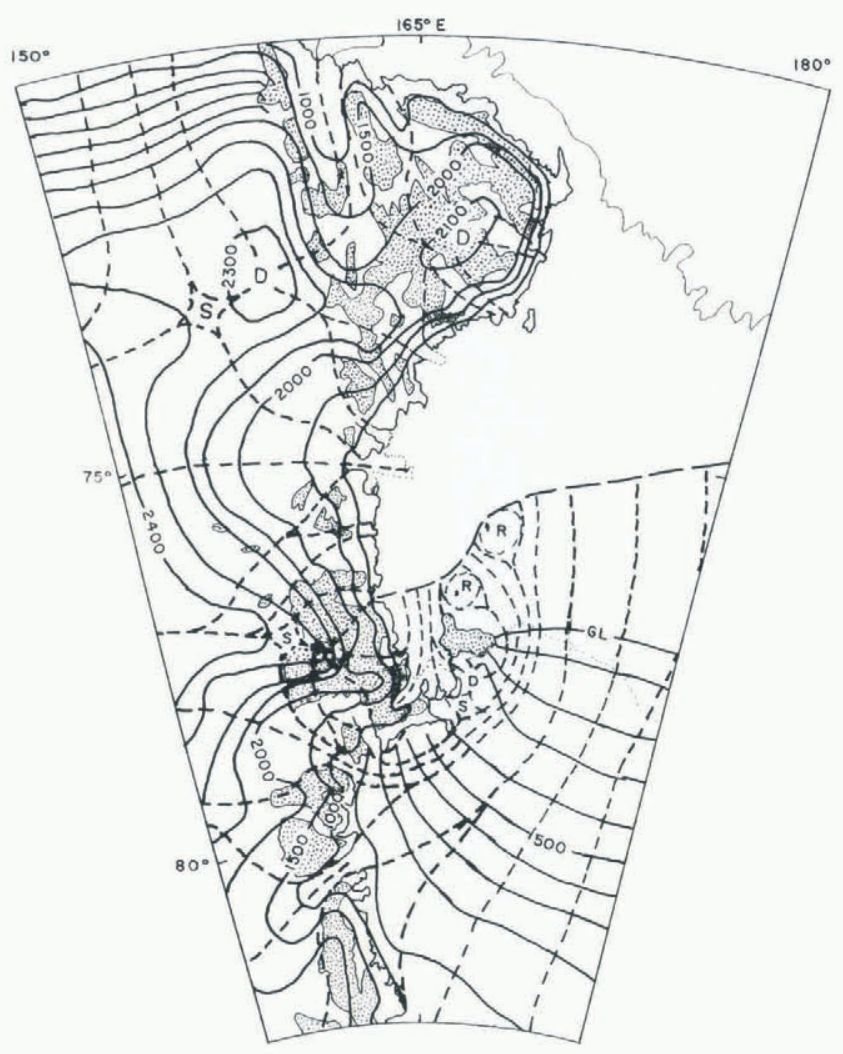

Fig. 11. 8000 BP ice-sheel reconstruction. Symbols, patterns and contours as in Figure 7. " $R$ " = ice rises, where shelf ice grounds on shallows. The grounding line has retreated to a position in southern McMurdo Sound and all shelf ice in the sound is of local origin or from Koettlitz and Ferrar Glaciers. Position of the ice-shelf margin north of Franklin and Beaufort Islands is approximate. 
Islands where the ice shelf may have grounded. Ice flow in McMurdo Sound continued to be northward throughflow, as at $12000 \mathrm{BP}$, with the same sources as at that time.

\section{BP}

The grounding line retreated to an unknown position south of Minna Bluff by $4000 \mathrm{BP}$ (Fig. 12), because numerous younger radiocarbon-dated macrofossils have been recovered from the MIS in southern McMurdo Sound (Kellogg and others, 1990). The calving margin was south of Cape Bird, where the oldest ${ }^{14} \mathrm{C}$ dated raised beaches occur at $4885 \mathrm{BP}$ (Dochat, 1994). On the Victoria Land coast, the calving margin was probably at Marble Point or even further south, consistent with a penguinguano date of 3905 BP (Baroni and Orombelli, 1994). The ice-flow pattern in McMurdo Sound was much like that of today, although ice from Koettlitz, Blue and Ferrar Glaciers probably occupied some of the westernmost part of the sound. The ice-shelf frontal position shown east of Ross Island is unconstrained. Grounding-line retreat continued after $4000 \mathrm{BP}$ to the modern position but when this position was attained is unknown. Also unknown is whether the grounding line continues to retreat, if it has attained a temporary stable position, or if it is now advancing.

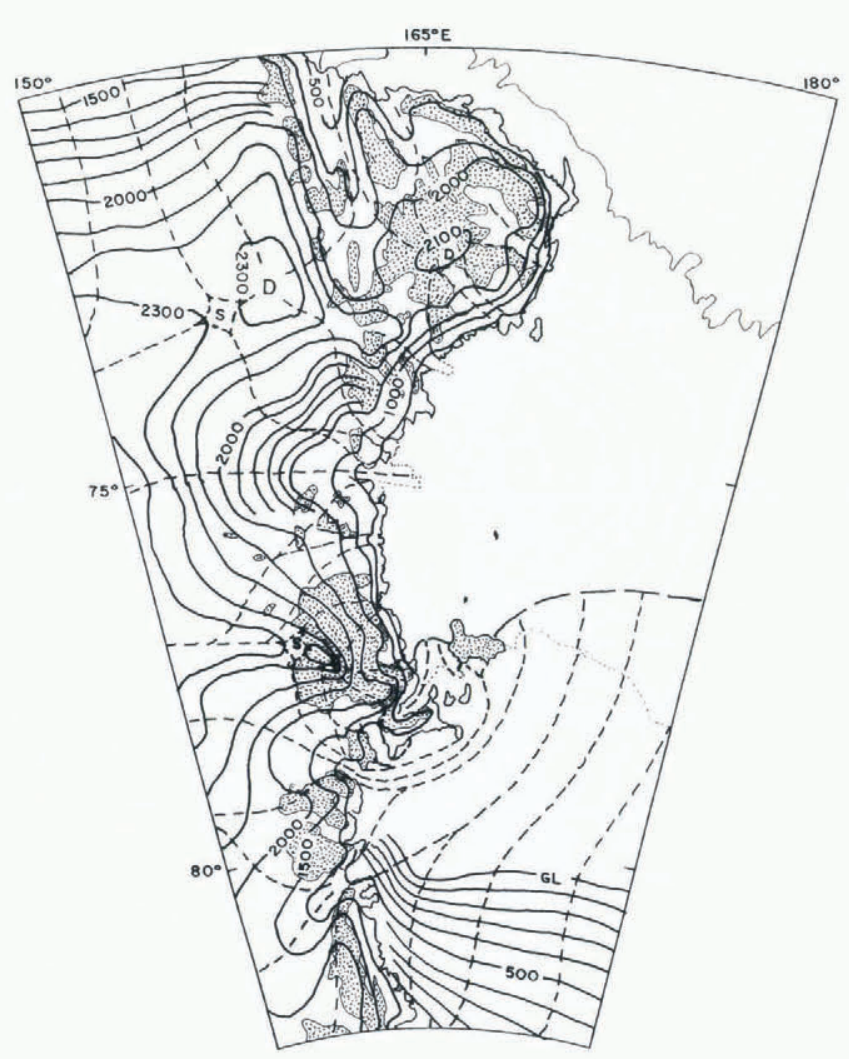

Fig. 12. 4000 BP ice-sheet reconstruction. Symbols, patterns and contours as in Figure 7. The grounding line has retreated to a position south of Minna Bluff and the Ross Ice Shelf margin is approaching its present position. Shelf ice in McMurdo Sound is from Koettlitz Glacier and local precipitation, and some Mulock Glacier ice. Ice-shelf marginal position in McMurdo Sound is poorly constrained but south of Cape Bird.

\section{DISCUSSION}

The observation-based reconstructions at the LGM in Figure 7 and during deglaciation in Figures 9-12 have very low ice-sheet flowline profiles that are as low as or lower than any found in West Antarctica today. This can be explained in two ways. First, when sea level lowered $120 \mathrm{~m}$ or more during the last glaciation and caused the Ross Ice Shelf to become grounded in the Ross Sea embayment, the ice surface would have been virtually horizontal and many millennia would be required at present-day rates of accumulation to produce flowline profiles for nearly steady-state ice-sheet flow that are observed today for the East Antarctic ice sheet, especially if the bed became frozen upon grounding and remained frozen. In this case, the low flowline profiles existed because grounding was so late in the glaciation cycle that time was merely insufficient to produce the steeper steady-state flowline profiles typical of East Antarctica today. However, if the bed was thawed and remained thawed when the Ross Ice Shelf grounded, then East Antarctic outlet glaciers through the Transantarctic Mountains (specifically Byrd, Mullock and David Glaciers in our study) may have continued as ice streams occupying the linear troughs that extend seaward across the continental shelf from these outlet glaciers. In this case, the low flowline profiles existed because watersaturated sediments in the troughs provided low traction that allowed the low flowline profiles typical of West Antarctic ice streams today. As in West Antarctica, these sediments must be either very thick or continuously resupplied in order to prevent fast ice-stream flow from becoming slow ice-sheet flow as glacial erosion transported the sediments seaward, thereby exposing hightraction bedrock in the troughs.

A field test of the two hypotheses would involve finding thick sediment wedges on the continental slope beyond the Ross Sea embayment. If none exist, ice-shelf grounding late in the glaciation cycle may not have allowed sufficient time for ice streams to deposit their wedges before rising sea level forced grounding lines to retreat into the Ross Sea embayment. Field studies would then not provide a definitive test of the competing hypotheses.

Glaciological theory can provide a test of each hypothesis by using ice-sheet modeling to reconstruct flowline profiles that match the profiles in Figures 7 and 9-12 for the deglaciation hemi-cycle. Following Hughes (1992), the surface profile along a flowline can be calculated by combining the force-balance and massbalance equations. A simultaneous solution of these two equations results in the following expression for the surface slope:

$$
\begin{aligned}
& \frac{\Delta h}{\Delta x}=\left(1-\frac{\rho_{\mathrm{I}}}{\rho_{\mathrm{W}}}\right)\left(\frac{P_{\mathrm{W}}}{P_{\mathrm{I}}}\right)^{2} \\
& \quad\left\{\frac{h_{\mathrm{I}} a}{a x+h_{0} u_{0}}-\frac{h_{\mathrm{I}}^{2} R^{n-1}}{a x+h_{0} u_{0}}\left[\frac{\rho_{\mathrm{I}} g_{\mathrm{Z}} h_{\mathrm{I}}}{4 A}\left(1-\frac{\rho_{\mathrm{I}}}{\rho_{\mathrm{W}}}\right)\left(\frac{P_{\mathrm{W}}}{P_{\mathrm{I}}}\right)^{2}\right]^{n}\right\} \\
& \quad+\frac{h_{\mathrm{I}}}{2}\left(1-\frac{\rho_{\mathrm{I}}}{\rho_{\mathrm{W}}}\right) \frac{\Delta}{\Delta x}\left(\frac{P_{\mathrm{W}}}{P_{\mathrm{I}}}\right)^{2}+\frac{2 \tau_{\mathrm{s}}}{\rho_{\mathrm{I}} g_{\mathrm{Z}} w}+\frac{\tau_{\mathrm{o}}}{\rho_{\mathrm{I}} g_{\mathrm{Z}} h_{\mathrm{I}}}
\end{aligned}
$$

where $\Delta h$ is the change of ice height $h$ in horizontal 
length increment $\Delta x$ along length $x$ of a flowline, with $x=0$ at the grounding line and $x=L$ at the ice divide, $h_{\mathrm{I}}$ is ice thickness along the flowline, $w$ is width of the flow band that encloses the flowline, $a$ is average accumulation rate along the flow band, and $h_{0}$ and $u_{0}$ are the respective grounding-line ice thickness and velocity at $x=0, \tau_{\mathrm{s}}$ is side shear stress alongside the flow band, $\tau_{\mathrm{o}}$ is basal shear stress beneath the flow band, $g_{\mathrm{Z}}$ is gravity acceleration, $\rho_{\mathrm{I}}$ is ice density, $\rho_{\mathrm{W}}$ is water density, $P_{\mathrm{I}}=\rho_{\mathrm{I}} g_{\mathrm{Z}} h_{\mathrm{I}}$ is basal ice pressure, $P_{\mathrm{W}}=\rho_{\mathrm{W}} g_{\mathrm{Z}} h_{\mathrm{W}}$ is basal water pressure equivalent to that beneath a water column of height $h_{\mathrm{W}}$ and $P_{\mathrm{W}} / P_{\mathrm{I}}=\rho_{\mathrm{W}} h_{\mathrm{W}} / \rho_{\mathrm{I}} h_{\mathrm{I}}$ is a basal buoyancy factor such that $P_{\mathrm{W}} / P_{\mathrm{I}}=0$ for ice-sheet flow over a frozen bed, $P_{\mathrm{W}} / P_{\mathrm{I}}=1$ for ice-shelf flow over sea water, and $0<P_{\mathrm{W}} / P_{\mathrm{I}}<1$ for ice-stream flow over wet sediments, $A$ and $n$ give the respective hardness and viscoplastic properties of ice, the effect of longitudinal deviator stress $\sigma_{x x}^{\prime}$ is contained in the first term, the effect of longitudinal deviator stress gradient $\Delta \sigma_{x x}^{\prime} / \Delta x$ is contained in the second term, the effect of transverse shear stress $\sigma_{x y}$ is contained in the third term, the effect of vertical shear stress $\sigma_{x z}$ is contained in the fourth term, and $R$ $=\left[1+\left(\sigma_{x y} / \sigma_{x x}^{\prime}\right)^{2}+\left(\sigma_{x z} / \sigma_{x x}^{\prime}\right)^{2}\right]$ when transverse deviator stress $\sigma_{y y}^{\prime}$ is ignored.

Equation (1) can be used to reconstruct surface-ice profiles along the entire length of a flowline, including icesheet flow, ice-stream flow and ice-shelf flow, merely by allowing $P_{\mathrm{W}} / P_{\mathrm{I}}$ to vary along the flowline. For example, consider the two extremes of ice-sheet flow over a frozen bed and ice-shelf flow over sea water in a flow band of constant width. Equation (1) gives flowline slopes for linear ice-sheet flow over a frozen bed, for which $P_{\mathrm{W}} / P_{\mathrm{I}}=\tau_{\mathrm{s}}=0$ :

$$
\frac{\Delta h}{\Delta x}=\frac{\tau_{\mathrm{o}}}{\rho_{\mathrm{I}} g_{\mathrm{Z}} h_{\mathrm{I}}} .
$$

Equation (1) also gives flowline slopes for linear ice-shelf flow, for which $\tau_{\mathrm{o}}=0$ and $P_{\mathrm{W}} / P_{\mathrm{I}}=1$ :

$$
\begin{array}{r}
\frac{\Delta h}{\Delta x}=\left(1-\frac{\rho_{\mathrm{I}}}{\rho_{\mathrm{W}}}\right)\left\{\frac{h_{\mathrm{I}} a}{a x+h_{0} u_{0}}-\frac{h_{\mathrm{I}}^{2} R^{n-1}}{a x+h_{0} u_{0}}\right. \\
\left.\left[\frac{\rho_{\mathrm{I}} g_{\mathrm{Z}} h_{\mathrm{I}}}{4 A}\left(1-\frac{\rho_{\mathrm{I}}}{\rho_{\mathrm{W}}}\right)\right]^{n}\right\}+\left(\frac{2 \tau_{\mathrm{s}}}{\rho_{\mathrm{I}} g_{\mathrm{Z}} w}\right) .
\end{array}
$$

Equation (2) can be integrated to give the parabolic flowline profile for ice-sheet flow when $\tau_{\mathrm{o}}$ is constant and the bed is horizontal. Equation (3) gives the ice-thickness gradient $\Delta h_{\mathrm{I}} / \Delta x=(\Delta h / \Delta x) /\left(1-\rho_{\mathrm{I}} / \rho_{\mathrm{W}}\right)$ for floating ice that Oerlemans and Van der Veen (1984) derived for $R=1$ and $\tau_{\mathrm{s}}=0$.

The flow law of ice can be integrated to give the average creep velocity at position $x$ along the flowline:

$$
u_{\mathrm{c}}=\frac{2 h_{\mathrm{I}}}{n+2}\left(\frac{\tau_{\mathrm{o}}}{A}\right)^{n} ;
$$

the sliding law of ice for ice-sheet flow can be modified to include ice-stream flow by including $P_{\mathrm{W}} / P_{\mathrm{I}}$. The sliding velocity is then (Hughes, 1992):

$$
u_{\mathrm{s}}=\frac{\left(\tau_{\mathrm{o}} / B\right)^{m}}{\left(1-P_{\mathrm{W}} / P_{\mathrm{I}}\right)^{2 m}}
$$

where $B$ includes bed-roughness factor $\wedge / \wedge^{\prime}$ for ice sliding over bedrock bumps of critical height $\wedge$ and spacing $\wedge^{\prime}$ and $m=(n+1) / 2$ in the Weertman (1957) theory of ice sliding over wet bedrock, $P_{\mathrm{W}} / P_{\mathrm{I}}=0$ when no wet sediments cover bedrock, $P_{\mathrm{W}} / P_{\mathrm{I}}=1$ when wet sediments bury bedrock bumps and $0<P_{\mathrm{W}} / P_{\mathrm{I}}<1$ when some bumps are not buried. Note that $\tau_{\mathrm{o}} \rightarrow 0$ as $P_{\mathrm{W}} / P_{\mathrm{I}} \rightarrow 1$, so $u_{\mathrm{S}}$ is indeterminate in Equation (5) when ice-stream flow becomes ice-shelf flow beyond the grounding line.

For ice-sheet flow over bedrock, $\tau_{\mathrm{o}}=\left(\tau_{\mathrm{o}}\right)_{\mathrm{c}}$ for creep over a frozen bed according to Equation (4), and $\tau_{\mathrm{o}}=\left(\tau_{\mathrm{o}}\right)_{\mathrm{s}}$ for sliding over a thawed bed according to Equation (5), where $\left(\tau_{\mathrm{o}}\right)_{\mathrm{c}}>\left(\tau_{\mathrm{o}}\right)_{\mathrm{s}}$, because a frozen bed provides more traction to resist sliding. When $a$ and $w$ are constant and $P_{\mathrm{W}} / P_{\mathrm{I}} \rightarrow 0$ along a flowline, Hughes (1981) showed that $\left(\tau_{\mathrm{o}}\right)_{\mathrm{c}}$ and $\left(\tau_{\mathrm{o}}\right)_{\mathrm{s}}$ are:

$$
\begin{aligned}
& \left(\tau_{\mathrm{o}}\right)_{\mathrm{c}}=\left[\frac{(n+2) \rho_{\mathrm{I}} g_{\mathrm{Z}} a A^{n}(L-x)^{(n+1) / n}}{4\left[L^{(n+1) / n}-(L-x)^{(n+1) / n}\right]}\right]^{1 /(n+1)} \\
& \left(\tau_{\mathrm{o}}\right)_{\mathrm{s}}=\left[\frac{(m+1) \rho_{\mathrm{I}} g_{\mathrm{Z}} a^{2} B^{2 m}(L-x)^{(2 m+1) / m}}{(2 m+1)\left[L^{(m+1) / m}-(L-x)^{(m+1) / m}\right]}\right]^{1 /(2 m+1}
\end{aligned}
$$

If $f$ is the thawed fraction of the bed, $\phi_{\mathrm{s}}$ and $\phi_{\mathrm{c}}$ are factors that allow for variable accumulation rates and flow-band widths along the flowline and $P_{\mathrm{W}} / P_{\mathrm{I}}$ varies along the flow band, because wet sediments cover part or all of bedrock, then $\left(\tau_{\mathrm{o}}\right)_{\mathrm{s}}$ in Equation $(7)$ is multiplied by $\left(1-P_{\mathrm{W}} / P_{\mathrm{I}}\right)^{4 m /(2 m+1)}$ and $\tau_{0}$ for both ice-sheet flow and ice-stream flow is given by:

$$
\tau_{\mathrm{o}}=f \phi_{\mathrm{s}}\left(\tau_{\mathrm{o}}\right)_{\mathrm{s}}\left(1-P_{\mathrm{W}} / P_{\mathrm{I}}\right)^{4 m /(2 m+1)}+(1-f) \phi_{\mathrm{c}}\left(\tau_{\mathrm{o}}\right)_{\mathrm{c}} .
$$

Hughes (1981) included glacio-isostatic depression of bedrock beneath ice-sheet flowlines by introducing the ratio $r$ of lowered bed elevation to lowered surface elevation due to isostatic depression. For a bed lowering beneath thickening ice:

$$
r=r_{\mathrm{o}}\left(1-\exp \left(-t / t_{\mathrm{o}}\right)\right)
$$

where $r_{\mathrm{o}} \approx \frac{1}{3}$ for isostatic equilibrium, $t$ is time since the ice load was applied and $t_{\mathrm{o}}$ is the relaxation time. For a bed rebounding beneath thinning ice:

$$
r=r_{\mathrm{a}} \exp \left(-t / t_{\mathrm{o}}\right)
$$

where ice began to thin at $t=0$ and $r_{\mathrm{a}}$ is given at time $t$ in Equation (9) when thickening ended and thinning began.

Equations $(6)-(10)$ can be incorporated into a numerical solution of Equation (1) by setting $\Delta h=h_{i+1}-h_{i}$ and $h_{\mathrm{I}}=h-h_{\mathrm{R}}$, where $i$ is the number of $\Delta x$ steps from the grounding line to distance $x$ along the flowline and $h_{\mathrm{R}}$ is bedrock height above (positive $h_{\mathrm{R}}$ ) or depth below (negative $h_{\mathrm{R}}$ ) present-day sea level. If $h^{*}$ is the isostatically lowered surface, $h_{\mathrm{R}}^{*}$ is the isostatically lowered bed and $h_{\mathrm{M}}$ is $h_{\mathrm{R}}$ at the LGM ice margin where isostatic adjustments are small enough to ignore (Hughes, 1981):

$$
\begin{aligned}
& h=h_{\mathrm{M}}+(1+r)^{\frac{1}{2}}\left(h^{*}-h_{\mathrm{M}}\right) \\
& h_{\mathrm{R}}^{*}=h^{*}-(1+r)\left(h^{*}-h_{\mathrm{M}}\right)+(1+r)^{\frac{1}{2}}\left(h_{\mathrm{R}}-h_{\mathrm{M}}\right) .
\end{aligned}
$$


Since $r$ varies much more slowly than $\Delta h$ over distance $\Delta x$, Equation (1) can be written as the following initialvalue finite-difference recursive formula for the glacioisostatically lowered ice surface along a flowline:

$$
\begin{aligned}
& h_{i+1}^{*}=h_{i}^{*}+\frac{\left(1-\rho_{\mathrm{I}} / \rho_{\mathrm{W}}\right)}{(1+r)^{\frac{1}{2}}}\left(\frac{P_{\mathrm{W}}}{P_{\mathrm{I}}}\right)_{i}^{2} \\
& \quad\left\{\frac{a\left[h_{\mathrm{M}}+(1+r)^{\frac{1}{2}}\left(h^{*}-h_{\mathrm{M}}\right)-h_{\mathrm{R}}\right]_{i}}{a x+h_{0} u_{0}}\right. \\
& -\frac{\left[h_{\mathrm{M}}+(1+r)^{\frac{1}{2}}\left(h^{*}-h_{\mathrm{M}}\right)-h_{\mathrm{R}}\right]_{i}^{n+2}}{a x+h_{0} u_{0}} \\
& \left.\quad\left[\frac{\rho_{\mathrm{I}} g_{\mathrm{Z}}}{4 A}\left(1-\frac{\rho_{\mathrm{I}}}{\rho_{\mathrm{W}}}\right)\left(\frac{P_{\mathrm{W}}}{P_{\mathrm{I}}}\right)_{i}^{2 c}\right]^{n}\right\} \Delta x \\
& +\left\{\frac{(1+r)^{\frac{1}{2}}\left[h_{\mathrm{M}}+(1+r)^{\frac{1}{2}}\left(h^{*}-h_{\mathrm{M}}\right)-h_{\mathrm{R}}\right]_{i}}{2}\right. \\
& \left.\quad\left(1-\frac{\rho_{\mathrm{I}}}{\rho_{\mathrm{W}}}\right)_{\frac{\Delta}{\Delta x}}\left(\frac{P_{\mathrm{W}}}{P_{\mathrm{I}}}\right)_{i}^{2}\right\} \Delta x+\left\{\frac{2}{\rho_{\mathrm{I}} g_{\mathrm{Z}}}\left(\frac{\tau_{\mathrm{s}}}{w}\right)_{i}\right. \\
& \left.+\frac{\left[f \phi_{\mathrm{s}}\left(\tau_{\mathrm{o}}\right)_{\mathrm{s}}\left(1-\frac{P_{\mathrm{W}}}{P_{\mathrm{I}}}\right)^{4 m /(2 m+1)}+(1-f) \phi_{\mathrm{c}}\left(\tau_{\mathrm{o}}\right)_{c}\right]_{i}}{\rho_{\mathrm{I}} g_{\mathrm{Z}}\left[h_{\mathrm{M}}+(1+r)^{\frac{1}{2}}\left(h^{*}-h_{\mathrm{M}}\right)-h_{\mathrm{R}}\right]_{i}}\right\} \Delta x .
\end{aligned}
$$

All terms having a subscript $i$ must be evaluated at each step $i=x / \Delta x$ along the flowline. As with Equation (1), Equation (13) can give surface profiles for any combination of ice-sheet flow, ice-stream flow and ice-shelf flow along a flowline. In addition, it can give these profiles for any history of glacio-isostatic adjustments beneath the flowline. Solutions of Equation (13) begin at the grounding line, where $i=0$ and $h_{0}=\left(\rho_{\mathrm{W}} / \rho_{\mathrm{I}}\right) h_{\mathrm{W}}$ in order to satisfy the buoyancy requirement.

Using Equation (13) to produce flowline profiles that match the observation-based profiles in Figure 7 and Figures 9-12 requires knowing $P_{\mathrm{W}} / P_{\mathrm{I}}, r, a, A, B, n, m$, $\tau_{\mathrm{s}}, w, h_{\mathrm{R}}, f, \phi_{\mathrm{s}}$ and $\phi_{\mathrm{c}}$ along flowlines, where $\phi_{\mathrm{s}}$ and $\phi_{\mathrm{c}}$ depend on how $a$ and $w$ vary along flowlines and $A, B, n$ and $m$ are obtained from the flow and sliding laws of glacial ice. Some simplifications are possible. For example, $\tau_{\mathrm{s}}=0$ for ice-sheet flow and can be ignored when $w>>h_{1}$ for ice-stream flow, which is usually the case; however, see Whillans and Van der Veen (1993). In addition, ice elevations are only weakly dependent on $a$ and $w$, so $\phi_{\mathrm{s}}=\phi_{\mathrm{c}}=1$ is a reasonable approximation, especially since $a$ is not known accurately during deglaciation. This leaves $P_{\mathrm{W}} / P_{\mathrm{I}}, r, f$ and $h_{\mathrm{R}}$ as the major variables to be specified along flowlines. Simultaneous solutions of the equations of heat transport and mass transport allow $P_{\mathrm{W}} / P_{\mathrm{I}}$ and $f$ to be calculated along flowlines, together with accurate determinations of $A, B$, $n$ and $m$. This is possible, in principle, from timedependent three-dimensional ice-sheet computer models but the modeling work has scarcely begun and the models must include the physics of wet deforming sediments beneath the ice (e.g. Lingle and Brown, 1987; MacAyeal, 1989). Ideally, $r$ should be obtained from a physically based global glacio-isostatic model (e.g. Clark and Lingle, 1979; Lingle and Clark, 1985) instead of empirically based Equations $(9)$ and $(10)$. Only $h_{\mathrm{R}}$ can be readily obtained from geophysical profiling but even this is lacking along the entire lengths of flowlines in Figure 7 and Figures 9-12.

Can matching observation-based low flowline profiles in Figure 7 and Figures 9-12 to theoretical profiles using Equation (13) decide between the two possibilities that we have postulated? The low profiles allow either ice that thickens slowly, because it is in nearly stagnant ice-sheet flow over a frozen bed, or ice that cannot thicken at all, because it is in rapid ice-stream flow over water-soaked sediments. Low flowline profiles for nearly stagnant icesheet flow over a frozen bed are obtained from Equation (13) when $P_{\mathrm{W}} / P_{\mathrm{I}}=0, f=0$ and $\left(\tau_{\mathrm{o}}\right)_{\mathrm{c}}$ is small. Equation (6) gives $\left(\tau_{\mathrm{o}}\right)_{\mathrm{c}}$ and $a$ in Equation (6) is an effective iceaccumulation rate given by the actual ice-accumulation rate $\dot{a}$ minus the ice-thickening rate $\dot{h}_{\mathrm{I}}$. Ice is stagnant when the two rates are equal, so that $a=\dot{a}-\dot{h}_{\mathrm{I}}=0$. Therefore, the more stagnant the ice, the lower $\left(\tau_{\mathrm{o}}\right)_{\mathrm{c}}$ becomes in Equations (6) and (13). Low flowline profiles for fast ice-stream flow over water-soaked sediments are obtained from Equation (13) when $P_{\mathrm{W}} / P_{\mathrm{I}} \rightarrow 1, f=1, \tau_{\mathrm{s}}$ is small and $w$ is large. A fast wide ice stream will have a small $\tau_{\mathrm{s}}$ and a large $w$ because thermal and strain softening become concentrated in lateral shear zones under these conditions. This is the case for the floating part of Byrd Glacier today (Hughes, 1977). Since the two possibilities are end members in the spectrum of ice-sheet dynamics, it is not unreasonable to expect ice-sheet models to distinguish between these possibilities, despite the formidable problems that the models must address.

\section{GONGLUSIONS}

The reconstructions presented here represent a first attempt to understand interactions between East Antarctic and West Antarctic ice during the complex groundingline and calving-margin retreat that characterized deglaciation from the LGM in the Ross Sea. Sea-level rise certainly played a major role in this retreat. Although many of our marginal and grounding-line positions are poorly constrained, we believe that our approach, combining glaciological considerations with glacial geologic investigations of coastal and ice-shelf deposits, has the potential to yield additional insights into the interactions between these ice sheets. Our reconstructions are subject to refinement as additional constraining geologic data become available. An example is the uncertainty regarding the LGM grounding-line position in the northwestern Ross Sea. We suspect that future work will show the LGM position was near the shelf break rather than near Coulman Island. If we are correct, rapid grounding-line retreat probably occurred in this sector when sea level began to rise after $22000 \mathrm{BP}$. This is compatible with the inherent instability of marine-based ice-sheet grounding lines much like modern fluctuations along the Siple Coast. Data from coastal deposits between McMurdo Sound and Terra Nova Bay should provide important information to better constrain reconstructions for the period from the LGM to $8000 \mathrm{BP}$. The complete lack of data south of Minna Bluff currently hinders improvements in the grounding-line positions after about $8000 \mathrm{BP}$ but no studies of this area have been made. In particular, much 
more sea-floor bathymetric data in McMurdo Sound and beneath the MIS and Ross Ice Shelf are needed before a deglaciation model can be properly constrained. Also, more velocity measurements are needed on the MIS. These data could be obtained from Landsat images or aerial photographs, using the method of Lucchitta and others (1989) and MacDonald and others (1989). The WAIS initiative should be expanded to include these sorts of studies, if we are to ever realize the WAIS goals of fully understanding the Ross Sea deglaciation history.

Our analysis shows that glacial erratics derived from the Transantarctic Mountains and deposited on the MIS, and ice with high negative $\delta^{18} \mathrm{O}$ values imbedded in the MIS, cannot be explained by the modern ice-flow regime. They almost certainly record a former ice-flow regime when ice derived from Mulock Glacier was advected into southern McMurdo Sound. The locations where these samples were found, combined with our reconstructions, suggest that emplacement occurred during the LGM or perhaps during deglaciation but prior to about $4000 \mathrm{BP}$, by which time the modern ice-flow regime was established.

Our data allow us to evaluate two competing models for ice flow and extent during the LGM. The Drewry (1979) model fails to explain the boulder provenance and stable-isotope data, because ice from Skelton Glacier, rather than Mulock Glacier, would have dominated in southern McMurdo Sound. We prefer the Stuiver and others' (1981a) model, because it is easily explained by our glaciologic reconstruction, and a reasonable balance between preliminary ablation and precipitation data for the Skelton and Mulock Glaciers catchment areas, flow bands and lobes and, because the flow pattern appears compatible with stable-isotope and boulder-provenance data from the MIS. Additional supporting evidence is provided by a recent study of glacial and Holocene sediments and land forms at Cape Bird. Dochat (1994) concluded that ice flowed west and south around Cape Bird into McMurdo Sound during the LGM because no kenyite erratics were found at Cape Bird. The only known Antarctic source for kenyite is at Cape Royds on the west coast of Ross Island. On the mainland, kenyite was not deposited north of Marble Point, so flow into McMurdo Sound from a saddle on the ice divide north of Ross Island and flow around Ross Island met at Marble Point. If LGM ice flow followed the Drewry model, kenyite should be present in Ross Sea Drift at Cape Bird and no kenyite should exist south of Marble Point.

While we reject the Drewry model for the LGM, our data show that the northward through-flow of ice predicted by his model did prevail in McMurdo Sound during deglaciation, from about 12000 to $8000 \mathrm{BP}$. In fact, our glacial reconstruction for $12000 \mathrm{BP}$ for the area north and east of Ross Island resembles Drewry's (1979) reconstruction. Hence, we suggest that his model is excellent for the middle stages of deglaciation, if the contribution of ice from Skelton Glacier to the area north of Minna Bluff is omitted. The low flowline profiles in Figure 7 and Figures 9-12 can be explained as resulting from ice that was either largely stagnant or became highly dynamic after grounding, depending on whether the bed became frozen or remained thawed. Deciding between these two possibilities is a difficult but not impossible problem in ice-sheet modeling.

\section{ACKNOWLEDGEMENTS}

We thank C. Swithinbank, R. Ackert, C. Lepage and the helicopter pilots and crewmen of Antarctic Development Squadron VXE-6 for their field support. Discussions with C. Swithinbank, A. Gow and C. Bentley helped us develop our understanding of ice dynamics of the MIS. Support for our 1975-81 field work on the MIS was provided by U.S. National Science Foundation grants OPP75-15524, DPP-77-21083, DPP79-20112 and DPP8020000 to T.B.K. and D.E.K. T. Hughes acknowledges support from Battelle, Pacific Northwest Laboratories, for the LGM glaciological reconstruction.

\section{REFERENCES}

Anderson, J. B., S. S. Shipp, L. R. Bartek and D. E. Reid. 1992. Evidence for a grounded ice sheet on the Ross Sea continental shelf during the Late Pleistocene and preliminary paleodrainage reconstruction. In Elliot, D.H., ed. Contributions to Antarctic research III. Washington, DC, American Geophysical Union, 39-62. (Antarctic Research Series 57.

Baroni, C. and G. Orombelli. 1991. Holocene raised beaches at Terra Nova Bay, Victoria Land, Antarctica. Quat. Res., 36 2), 157-177.

Baroni, C. and G. Orombelli. 1994. Abandoned penguin rookeries as Holocene paleoclimatic indicators in Antarctica. Geology, 22, 23-26.

Bentley, C. R., J. W. Clough, K. C. Jezek and S. Shabtaie. 1979. Icethickness patterns and the dynamics of the Ross Ice Shelf, Antarctica. J. Glaciol., 24 (90), 287-294.

Bindschadler, R. A., ed. 1991, West Antarctic Ice Sheet Initiative. Volume 1. Science and implementation plan. Washington, DC, National Aeronautics and Space Administration. (CP-3115.

Blanchon, P. and J. Shaw. 1995. Reef drowning during the last deglaciation: evidence for catastrophic sea-level rise and ice-sheet collapse. Geology, 23 (1), 48.

Brady, H. T. 1978. Geological studies in southern Victoria Land, on Black Island, and on the Mc.Murdo Ice Shelf. Antarct. F. U.S., 13 4), 13-14.

Clark, J. A. and C. S. Lingle. 1979. Predicted relative sea-level changes (18,000 years B.P. to present) caused by late-glacial retreat of the Antarctic ice sheet. Quat. Res., 11 (3), 279-298.

Cook, J. C. 1963. Sesimic reconnaissance on an ice-covered Antarctic sea. J. Glaciol., $4(35)$, 559-568.

Debenham, F. 1919. A new mode of transportation by ice. $Q$. J. Geol. Soc. London, $\mathbf{7 5}$ 2), 51-76.

Debenham, F. 1949. The problem of the great Ross Barrier. Geogr. $\mathcal{J}$., $112(4$ 6), 1948, 196-218.

Debenham, F. 1961. A fish story from the Antarctic. Geogr. Mag., 34(6), $360-368$.

Denton, G.H., R. L. Armstrong and M. Stuiver. 1971. The Late Cienozoic glacial history of Antarctica. In Turekian, K. K., ed. The Late Cenozoic glacial ages. New Haven, CT, and London, Yale University Press, 267-306.

Denton, G. H., J. G. Bockheim, S. C. Wilson and M. Stuiver. 1989. Late Wisconsin and Early Holocene glacial history, inner Ross embayment, Antarctica. Quat. Res., 31 2), 151-182.

Dochat, T. M. 1994. Surficial stratigraphy and geomorphology of Cape Bird, Ross Island, Antarctica: implications for Late Wisconsin glaciation in the Ross Sea embayment. (M.Sc. thesis, University of Maine, Orono.

Drewry, D.J. 1979. Late Wisconsin reconstruction for the Ross Sea region, Antarctica. 7. Glaciol., 24 (90), 231- 244.

Drewry, D.J., ed. 1983. Antarctica: glaciological and geophysical folio. Cambridge, Scott Polar Research Institute.

Fairbanks, R.G. 1989. A 17,000-year glacio-eustatic sea level record: influence of glacial melting rates on the Younger Dryas event and deep-ocean circulation. Nature, 342 6250), 637-642.

Giovinetto, M.B., C.R. Bentley and C.B.B. Bull. 1989. Choosing between some incompatible regional surface-mass-balance data sets in Antarctica. Antarcl. J. U.S., 24 (1), 7-13.

Gow, A.J. 1967. Antarctic glaciological studies. Antarcl. J. U.S., 2(4), $121-122$.

Gow, A.J. and S. Epstein. 1972. On the use of stable isotopes to trace the 
origins of ice in a floating ice tongue. J. Geophys. Res., 77(33), 65526557.

Gow, A.J., W. F. Weeks, G. Hendrickson and R. Rowland. 1965. New light on the mode of uplift of the fish and fossiliferous moraines of the McMurdo Ice Shelf, Antarctica. J. Glaciol., 5 42), 813-828.

Hart, C. P. 1990. Holocene megafauna in McMurdo Ice Shelf sediments - fossilization and implications for glacial processes. Antarct. J. U.S., 25(2), 11-14.

Hayward, P.J. and P. D. Taylor. 1984. Fossil and recent Cheilostomata (Bryozoa) from the Ross Sea, Antarctica. 7. Nat. Hist., 18, 71-94.

Heine, J. C. and T. W. Speir. 1989. Ornithogenic soils of the Cape Bird Adélie penguin rookeries, Antarctica. Polar Biol., 10 (2), 89-99.

Howard-Williams, C., R. Pridmore, M. T. Downes and W. F. Vincent. 1989. Microbial biomass, photosynthesis and chlorophyll $a$ related pigments in the ponds of the McMurdo Ice Shelf, Antarctica. Antart. Sci., 1 2), 125-131.

Howard-Williams, C., R. D. Pridmore, P. A. Broady and W. F. Vincent. 1990. Environmental and biological variability in the McMurdo Ice Shelf ecosystem. In Kerry, K.R. and G. Hempel, eds. Antarctic ecosystems. Berlin, Springer-Verlag, 23-31.

Hughes, T. 1977. West Antarctic ice streams. Rev. Geophys. Space Phys., $15(1), 1-46$

Hughes, T.J. 1981. Numerical reconstruction of paleo-ice sheets. In Denton, G.H. and T.J. Hughes, eds. The last great ice sheets. New York, etc., John Wiley and Sons, 221-261.

Hughes, T. 1992. On the pulling power of ice streams. F. Glaciol., $38(128), 125-151$.

Kellogg, D. E. and T. B. Kellogg. 1987. Diatoms of the McMurdo Ice Shelf, Antarctica: implications for sediment and biotic reworking. Palaeogeogr., Palaeoclimatol., Palaeoecol., 60 (1-2), 77-96.

Kellogg, T.B., M. Stuiver, D. E. Kellogg and G.H. Denton. 1977. Marine microfossils on the McMurdo Ice Shelf. Antarct. J. U.S., $12(4), 82-83$.

Kellogg, T.B., R.S. Truesdale and L.E. Osterman. 1979. Late Quaternary extent of the West Antarctic ice sheet: new evidence from Ross Sea cores. Geology, 7, 249-253.

Kellogg, T. B., D. E. Kellogg and M. Stuiver. 1990. Late Quaternary history of the southwestern Ross Sea: evidence from debris bands on the McMurdo Ice Shelf, Antarctica. In Bentley, C. R., ed. Contributions to Antartic research I. Washington, DC, American Geophysical Union, 25-56. (Antarctic Research Series 50.)

Krissek, L. A. 1988. Sedimentation history of the Terra Nova Bay region, Ross Sea, Antarctica. Antarct. J. U.S., 23(5), $104-105$.

Lingle, C. S. and T.J. Brown. 1987. A subglacial aquifer bed model and water pressure dependent basal sliding relationship for a West Antarctic ice stream. In Van der Veen, C.J. and J. Oerlemans, eds. Dynamics of the West Antarctic ice sheet. Dordrecht, etc., D. Reidel Publishing Co., 249-285. (Glaciology and Quaternary Geology 4.)

Lingle, C. S. and J.A. Clark. 1985. A numerical model of interactions between a marine ice sheet and the solid Earth: application to a West Antarctic ice stream. 7. Geophys. Res., 90 C1), 1100-1114.

Lucchitta, B. K., H. M. Ferguson, F. J. Schafer, J. G. Ferrigno and R. S. Williams, Jr. 1989. Antarctic glacier velocities from Landsat images. Antarct. J. U.S., 24(5), 106-107.

MacAyeal, D. R. 1989. Large-scale ice flow over a viscous basal sediment: theory and application to Ice Stream B, Antarctica. $\mathcal{F}$. Geophys. Res., 94 B4), $4071-4087$.

McCrae, I. R. 1984. A summary of glaciological measurements made between 1960 and 1984 on the McMurdo Ice Shelf, Antarctica. Auckland, New Zealand, University of Auckland. School of Engineering. Department of Theoretical and Applied Mechanics. (Report 360.

MacDonald, T.R., J.G. Ferrigno, R.S. Williams, Jr and B. K. Lucchitta. 1989. Velocities of Antarctic outlet glaciers determined from sequential Landsat images. Antarc. J. U.S., 24 (5), 105-106.

Morgan, V. I. 1982. Antarctic ice sheet surface oxygen isotope values. $\mathcal{F}$. Glaciol., 28(99), 315-323.

Oerlemans, J. and C. J. van der Veen, eds. 1984. Ice sheets and climate, Dordrecht, etc., D. Reidel Publishing Co.

Paige, R. A. 1968. Map of McMurdo Sound, Antarctica. Port Hueneme, CA, Naval Civil Engineering Laboratory. (Drawing 68-17-1F.)

Reid, D.E. 1989. Quaternary marine geology of the northwestern Ross Sca. Antarct. J. U.S., 24(5), 128-130.

Shipp, S. S. and J. B. Anderson. 1994. High-resolution seismic survey of the Ross Sea continental shelf: implications for ice-sheet retreat behavior. Antarct. 7. U.S., 29(5), 137-138.

Speden, I.G. 1962. Fossiliferous Quaternary marine deposits in the McMurdo Sound region, Antarctica. N.Z. 7. Geol. Geophys., 5(5), 746-777.

Speir, T. W. and J.C. Cowling. 1984. Ornithogenic soils of the Cape Bird Adélie penguin rookeries, Antarctica. 1. Chemical properties. Polar Biol., 2 4), 199-205.

Stuart, A. W, and C. Bull. 1963. Glaciological observations on the Ross Ice Shelf near Scott Base, Antarctica. J. Glaciol., 4 (34), 399-414.

Stuiver, M., G. H. Denton, T. J. Hughes and J. L. Fastook. 1981a. History of the marine ice sheet in West Antarctica during the last glaciation: a working hypothesis. In Denton, G.H. and T.J. Hughes, eds. The last great ice sheets. New York, etc., John Wiley and Sons, $319-436$.

Stuiver, M., I.C. Yang, G.H. Denton and T.B. Kellogg. 1981b. Oxygen isotope ratios of Antarctic permafrost and glacier ice. In McGinnis, L. D., ed. Dry Valley Drilling Project. Washington, DC, American Geophysical Union, 131-139. (Antarctic Research Series 33. )

Suren, A. 1990. Microfauna associated with algal mats in melt ponds of the Ross Ice Shelf. Polar Biol., 10 5), 329-335.

Swithinbank, C. W. M. 1970. Ice movement in the McMurdo Sound area of Antarctica. International Association of Scientific Hydrology Publication 86 Symposium at Hanover 1968 - Antarctic Glaciological Exploration (ISAGE)), 472487.

Swithinbank, C.W. M., D. G. Darby and D. E. Wohlschlag. 1961. Faunal remains on an Antarctic ice shelf. Science, 133(3455), 764-766.

United States Geological Survey. 1972. Ross Ice Shelf, Antartica. Reston, VA, United States Geological Survey. (Antarctica sketch map, polar stereographic projection, scale $1: 1,000,000$.)

Weertman, J. 1957. On the sliding of glaciers. J. Glaciol., 3(21), 33-38.

Whillans, I. M. and C.J. van der Veen. 1993. New and improved determinations of velocity of Ice Streams B and C, West Antarctica. J. Glaciol., 39 (133), 483-490.

Zotikov, I.A. and A.J. Gow. 1967. The thermal and compositional structure of the Koettlitz ice tongue, McMurdo Sound, Antarctica. In Oura, H., ed. Physics of snow and ice. Vol. 1. Part 1. Sapporo, Hokkaido University. Institute of Low Temperature Science, 469-478. 